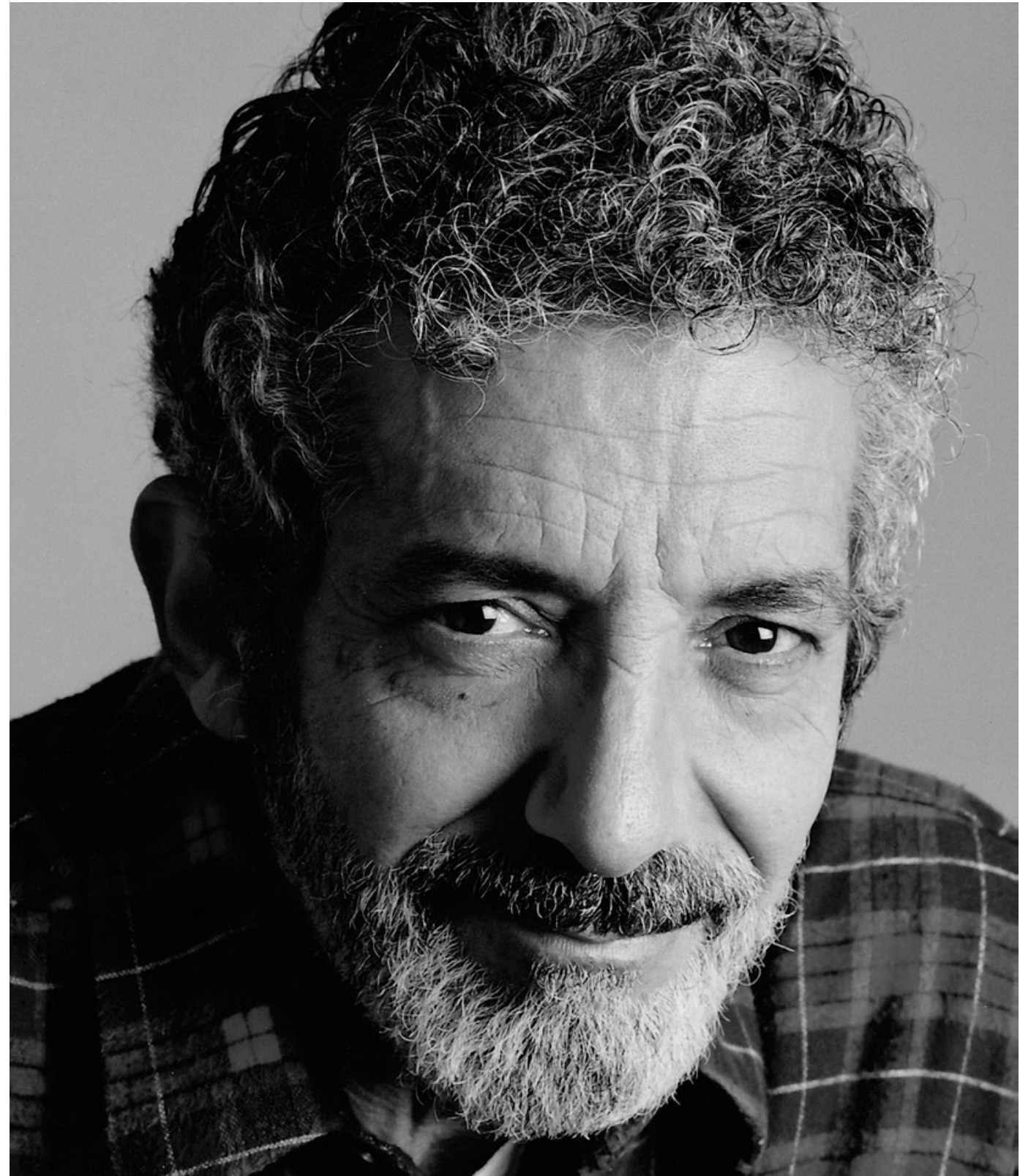

Fernando Gomes, 2001

[Arquivo pessoal de

Fernando Gomes].

\title{
Fernando Gomes
}

\section{Do "Pátio da Teatra" ao Teatro Nacional de São Carlos}

\section{Teresa Faria e Rita Martins}

Tendo-se iniciado no teatro aos trinta anos de idade num espectáculo do Teatro Experimental de Cascais em 1974, Fernando Gomes fechou aí a sua ligação ao escritório em que trabalhava, e desde então nunca mais deixou de representar, cantar, escrever e encenar. Como actor tornou-se notado na Casa da Comédia e ai escreveu os seus primeiros textos. Precursor do café-teatro em Portugal, tornou-se um dos maiores criadores do espectáculo teatro-musical português, com destaque especial para Maria! Não me mates que sou tua mãe!, em 1988. Contabilizam-se mais de 132 espectáculos no seu currículo, tendo sido dirigido por João Lourenço, Filipe La Féria, Diogo Infante, entre outros. Actualmente como encenador do Teatro Infantil de Lisboa - onde está desde 1990 -, Fernando Gomes tem recebido convites para encenar em múltiplas companhias, mas não prescinde dos "seus" actores de eleição - como Elsa Galvão e Isabel Ribas - com quem selou um pacto artístico pela criação da companhia Klássikus. O humor e o estilo inconfundiveis dos seus espectáculos são inseparáveis da sua personalidade, das suas paixões e das suas vivências de infância. Com um percurso artístico singular, Fernando Gomes passa com desenvoltura e criatividade do bar Acapulco ao Teatro Nacional de São Carlos, num trajecto sempre guiado pelos afectos, revelador dos valores e da sensibilidade de alguém que fez do palco a sua casa e dos actores a sua familia. 
"Páteo da Teatra", Nandinho e Nénè Arquivo pessoal de Fernando Gomes].

Fernando Gomes, fotografia da comunhão
Que idade tinhas quando fazias com os teus amigos as vossas peças no quintal? Devia ter à volta de dez anos. No bairro onde eu nasci, em S. Roque da Lameira [Porto], da minha idade só havia meninas, com quem brincava aos teatros. A minha casa tinha um quintal e era onde representávamos. Fazíamos variedades: cantávamos, representávamos, maquilhávamo-nos, vestiamo-nos, fantasiávamo-nos e fazíamos uns bilhetes com uns desenhinhos, umas florinhas, 25 tostões cada. Vendiamos aos vizinhos, que viam da janela. Era o "Pátio da Teatra".

Então, nessa altura já escrevias, encenavas, eras actor e figurinista?

A minha mãe tinha uma máquina de costura. Eu fazia ali saiotes em papel de jornal, ia dobrando, cosendo, e aquilo ficava muito teso e as saias ficavam todas armadas. [risos]. Piano e música nunca faltavam. Depois, eu escrevia uns diálogos. 0 que nós víamos era os filmes musicais americanos. 0 nosso sonho era ir para a América onde havíamos de ser muito felizes.

0 cinema faz parte do teu imaginário desde criança? Os meus pais iam uma vez por semana ao cinema e levavam-me, mesmo em pequenino. Ficava ao colo da minha mãe ou do meu pai e, muitas vezes, adormecia.

\section{E os estudos na Escola Oliveira Martins?}

0 meu pai queria que eu tirasse um curso, mas nunca tirei. Faltava à escola para ir ao Cinema Carlos Alberto que dava sempre duas sessões e eram bilhetes a três e quinhentos [3 \$50: três escudos e cinquenta centavos]. Era sempre um filme de cowboys e um musical ou dois filmes diferentes. Portanto, eu passava a tarde no Cinema Carlos Alberto. Quando eram aulas de duas horas é que era bom porque só tinha uma falta e estava duas horas fora da escola.

Quem eram os teus actores ou actrizes preferidos? A Doris Day. Eu vi os filmes todos da Doris Day. Ainda hoje gosto de os ver. Era o musical. A loura. Sempre tive um fascinio por louras no palco. É a loura simpática que canta, dança e representa. Tenho aí imensas cassetes dela, porque adoro. 0 primeiro filme que vi com ela foi o Calamity Jane As diabruras de Jane, que é extraordinário. A minha mãe dava-me dinheiro para livros e cadernos e eu depois comprava bilhetes para o cinema. Recordo-me, um dia, de ter ido ao Odeon - uma sala de cinema que já não existe, no Bonfim. Faltavam-me cinco tostões. A vontade era tanta que fui pedir a um senhor: "Ó senhor, dê-me cinco tostões que me faltam para comprar o bilhete!" $\mathrm{E}$ ele deu [risos].
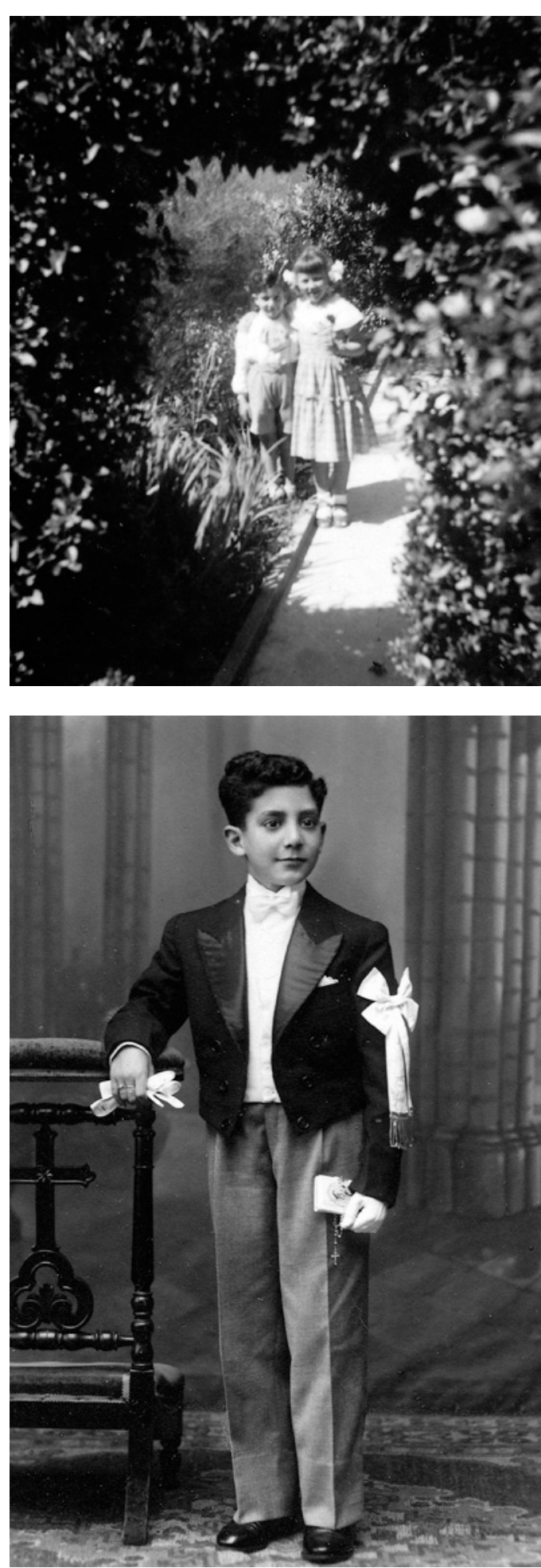

Os musicais de Hollywood marcaram o teu percurso artístico?

Sim, mas mais importante foi ter nascido num sítio onde havia música. 0 meu pai e a minha mãe tocavam piano e nós cantávamos. E a minha avó contava-me histórias fantásticas à noite, aquelas lendas e contos tradicionais, e eu adorava. Parece que estou a ver o sitio, ela sentada numa cadeirita. Eu, muito pequenito, ia logo para o colo dela para ela me contar a história. Já sabia que a meio adormecia e quando acordava já era no dia seguinte. Alguém me levava para a cama. 

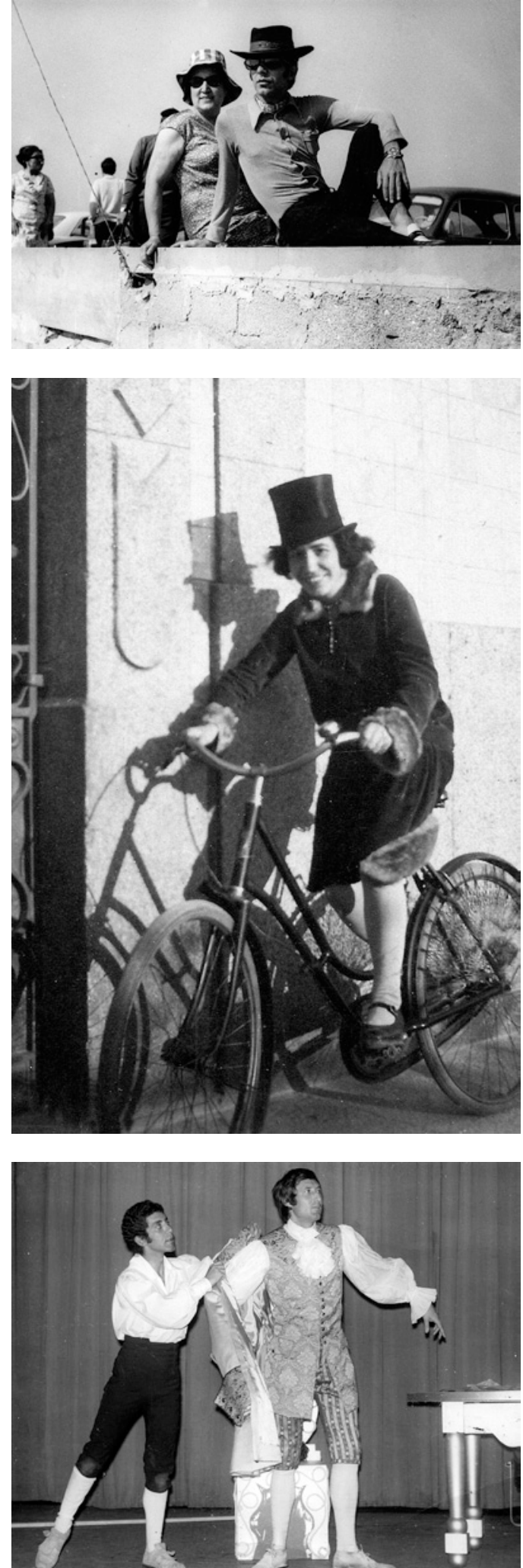

Aprendeste a tocar piano com a tua mãe?

Tentei, mas nunca consegui e os meus irmãos tocam todos, de ouvido. Não tenho jeito para o teclado. Cantar é que eu gosto. Cantávamos todos. Eu gosto muito de coleccionar coisas, tenho as pautas das músicas todas que ela tocava nessa época, dos anos 30. Eram as músicas que ela tinha quando era miúda. Tenho um lindo iô-iô que só me dá prazer... Esta música até já pus num espectáculo.
E quando faziam os saraus familiares?

0 meu pai era viajante e só vinha a casa aos fins-desemana. Tocava piano e nós cantávamos. Dime porque te quiero tanto e outras. Ainda me lembro das letras. Foi uma infância jeitosa. 0 meu pai também tinha uma história, inventada por ele e que nunca tinha fim. Era O homem da bengala de ferro, o mau da fita, um homem misterioso. 0 meu pai escrevia para jornais uns contos, umas histórias. Eu cresci com tudo isto à minha volta.

Além da música, das histórias que te contavam, havia livros?

0 meu pai tinha uma grande e variada biblioteca. Foi ai a primeira vez que eu li Camilo Castelo Branco, ainda miúdo. Também me atraíam os livros do Charles Dickens, Mark Twain, depois passei para John Steinbeck. Ainda recordo o primeiro livro que li dele: O Inverno do nosso descontentamento. Era uma colecção de grandes clássicos, desses que se lêem muito bem. 0 meu pai não era um letrado, era um homem simples, com a $4^{a}$ classe. Ele lia muito nas viagens, livros policiais, Agatha Christie. $\mathrm{Na}$ altura também os li.

\section{Houve mais alguém importante na tua infância?}

A minha tia Zélia, que era a estroina, era a mulher diferente. Com dezasseis anos saiu de casa, tirou um curso de altacostura e montou um atelier em Viana do Castelo: D. Zélia, Alta-costura, e assim ganhou a vida. Nunca casou e namorava muito. Era muito moderna. Foi das primeiras mulheres a usar calças; tão adiantada para a época que chegou a ser proibida de entrar em alguns cafés no Porto. Nos anos Vinte, Trinta, no Porto, havia café-concertos. Vinham orquestras da Alemanha e de outros sítios tocar nos cafés. E a minha tia ia sempre e gostava de conviver com eles. Não sei como é que falava, mas falava, [risos] adorava artistas. Namorou com o António Vilar. Sempre muito teatreira. Disseram-me muitas vezes: "És igual à tua tia Zélia." [risos] Ela fez teatro amador com o meu pai quando eram novos.

\section{Nos Modestos.}

Nos Modestos, precisamente... 0 meu pai tocava piano e as miúdas ficavam encantadas a olhar para ele, que era muito giro, um galã. E essa minha tia começou a levarme ao teatro. Era daquelas pessoas que vão falar com os artistas, que têm descaramento para isso. Eu não, eu era muito tímido e ainda sou. E um dia disse-me: "Ah, tens de conhecer a Laura Alves". Fomos ao Teatro Sá da Bandeira, onde estava em cena A rainha do ferro velho [de Garson Kanin, em 1960]. Lembro-me perfeitamente desta imagem:
Fernando Gomes com a mãe (anos 60) [Arquivo pessoal de Fernando Gomes].

Tia Zélia

[Arquivo pessoal de Fernando Gomes]

La serva padrona, de Pergolesi e G. A. Federico, direcção de Manuel de Passos, Teatro de São João, 1970 (Fernando Gomes, José de Castro) [Arquivo pessoal de Fernando Gomes]. 
a Laura Alves à porta do seu camarim, com um robe de cetim ou seda cor-de-rosa, muito querida, muito simpática, e eu feito parvo a olhar para ela. E a minha tia a pedirIhe se não podia "meter-me" no teatro, porque eu não tinha idade. Claro que não podia, coitada. Não vi essa peça, mas fiquei a conhecer a Laura Alves, que é o meu idolo. A minha tia viu a peça e gostou muito e no fim disse: "No último dia vamos oferecer dois ramos de flores à Laura Alves". Comprou malmequeres e um ramo de rosas de Santa Teresinha, para eu oferecer, com um bilhetinho dela. Chegámos ao teatro no dia seguinte à última representação. Não é que ela já lá não estava?! Tinha ido logo embora no fim da sessão. A minha tia pediu a uns senhores: "Olhem, levem isto numa caixa e dêem à D. Laura Alves quando chegarem a Lisboa." Passado um tempo recebi uma carta da Laura Alves, linda, tão simpática, a agradecer as flores e a explicar porque é que não estava. Preocupavam-se muito com os fãs. Tenho essa carta guardada religiosamente.

\section{Mas o que é que te fascinava quando olhavas para ela?}

A Laura Alves era o que havia de mais próximo dos artistas de cinema.

\section{E lembras-te do primeiro espectáculo que viste?} Dessa época, não. Mas inscrevi-me, entre os 14 e os 16 anos, como sócio do Teatro Experimental do Porto. Vi imensos espectáculos do TEP. Era maravilhoso. Um teatro pequenino, estreitíssimo, situado nas instalações de uma camisaria, cedida ao António Pedro. Tinha camarotes, balcão, plateia, mas era tudo em pequenino. Devia levar umas cinquenta pessoas.

\section{E nessa fase o que viste?}

Recordo-me dos actores: a Dalila Rocha, o João Guedes, a Alda Rodrigues e o Mário Jacques. Ficava fascinado com aquilo. Ao mesmo tempo via revistas. Lembro-me de uma actriz, muito engraçada, a Maria Domingas, que era nova, gira, e da Leónia Mendes, já mais "entrada". 0 que me fascinava na revista eram os momentos musicais, as canções, os bailados, a fantasia. Julgas que eu achava graça às "graças" e aos compères? Nenhuma. Lembro-me de ir ao Rivoli, ver o Teatro Nacional. Via tudo que aparecia: comédia, revista e o Teatro Nacional, que ia com a D. Amélia [Rey Colaço]. No Teatro de S. João, mas principalmente no Rivoli, eu recordo-me que houve uma altura em que eles estiveram lá, talvez um mês, e apresentaram o reportório todo, que era extraordinário. Todas as semanas uma peça diferente. Hoje em dia já não existem essas coisas, o que é pena. Mas houve duas peças que me impressionaram. Boa noite Betina, com a Laura Alves. Fu do Porto a Lisboa umas cinco vezes para ver o espectáculo. Quando ela foi para o Porto voltei a ir ver. Vi 10 vezes. E 0 tinteiro [de Carlos Muñiz]. Era o grande Armando Cortez. Fascinaram-me ele e a Carmen Dolores. Foi no Teatro de S. João pelo Teatro Moderno de Lisboa.

\section{0 que é que te atraiu em $O$ tinteiro [1961] e em Boa noite Betina [1960]?}

A Laura Alves era uma mulher ao nivel da Shirley MacLaine, uma actriz extraordinária, tão boa que ficavas ali preso. Era a única actriz que estava dois anos em cena com as lotações esgotadas. 0 corpo de baile era inglês e eu ainda me lembro de todos. Entravam a Manuela Maria, o Nicolau Breyner, estreante, o Ruy de Carvalho, Paulo Renato e também uma bailarina, a Yola, que era maravilhosa, fazia um striptease ao contrário, ou seja, vinha em biquíni e iase vestindo. Eram todos belissimos actores. 0 tinteiro marcou-me pelas interpretações extraordinárias da Carmen Dolores e do Armando Cortez. Era uma história sobre o desemprego. Recordo-me perfeitamente da cena em que ele se suicida. Via-se a luz do comboio a aproximar-se, e a imagem dele, de costas para o público... Uma encenação fantástica do Rogério de Carvalho. Ficas preso à cadeira e emocionas-te, porque o teatro deve emocionar.

\section{E a ópera?}

Comecei a ver ópera cedíssimo, no Porto, no Coliseu. Adoro ópera. 0 primeiro espectáculo que fiz foi uma ópera, o Elixir do amor [de Gaetano Donizetti, em 1965]. As óperas iam de Lisboa para o Porto e nem sempre levavam o corpo de baile, porque ficava mais económico. Então, mandavam as partituras para a escola e os alunos faziam-no. Estreeime no corpo de baile do Elixir do amor. Em 1970 entrei em La serva padrona [de Giovanni Battista Pergolesi], pelo Círculo Portuense de Ópera. Fazia uma personagem muda o Vespone. Depois também foi o Ballet Gulbenkian, no Rivoli do Porto, em 1971, com Petruska [de Igor Stravinski]. Já estive na Gulbenkian!!! Era um mundo fascinante. Eu tinha muito jeito para me movimentar, porque andei no ballet, no bailado clássico. Comecei na Academia de Bailado Clássico de Pirmin Trecu, onde conheci a Zita Seabra.

\section{A Zita Seabra?}

Era primeira bailarina da escola, extraordinária. E depois desapareceu, passou à clandestinidade. Estávamos ai pelos anos 50,60. Sempre gostei de bailado, mas nem me passava pela cabeça pedir dinheiro ao meu pai para me 


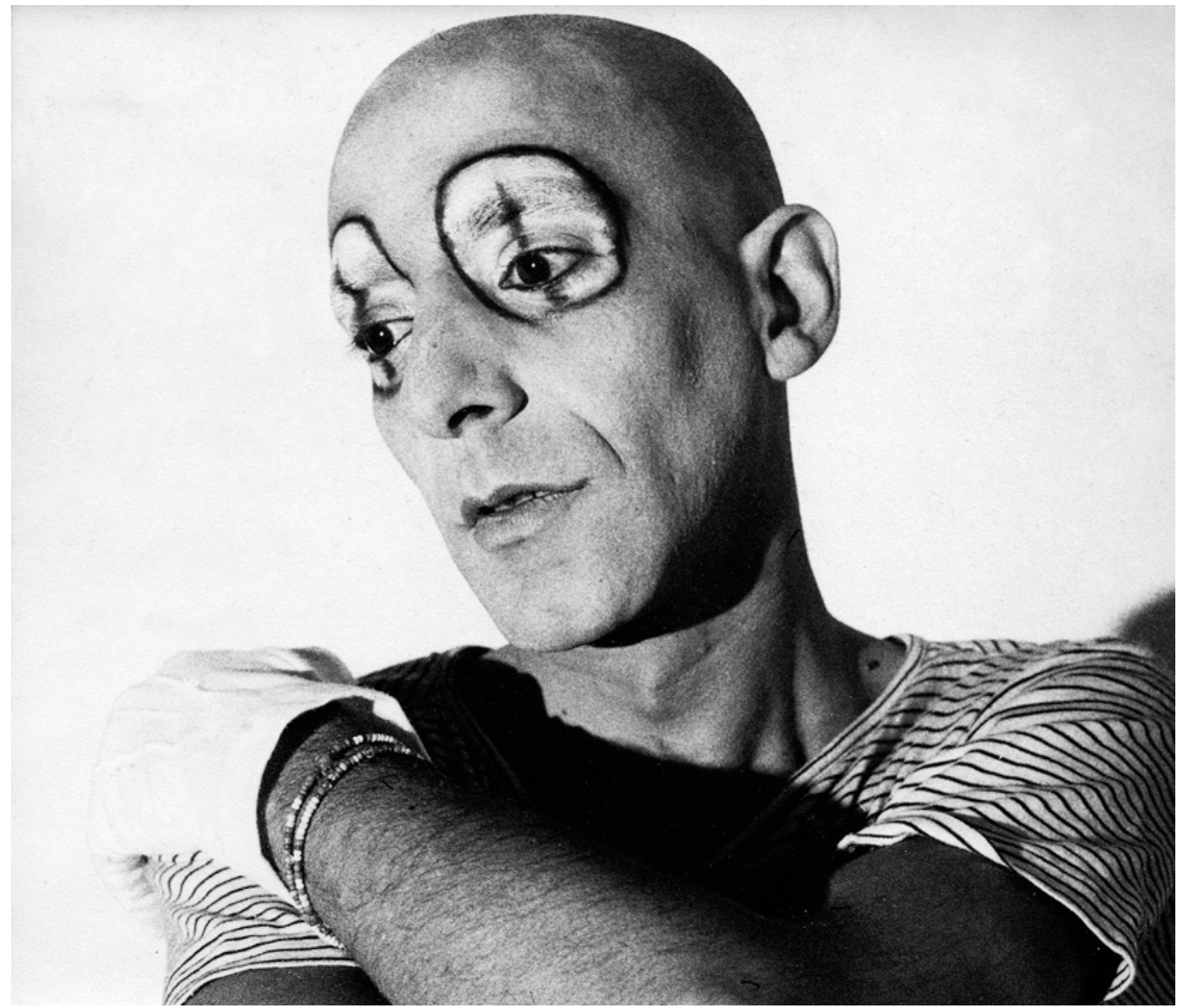

Fastudo! Faz-tudo!! Faz tudo!!!, enc. Filipe La Féria, Grupo de Trabalhadores de Teatro da Casa da Comédia, Casa da Comédia, 1979 (Fernando Gomes) [Arquivo pessoal de Fernando Gomes].

ir inscrever numa escola de bailado. E tinha vergonha, não tinha ninguém a quem confidenciar este sonho. E um dia fui a uma festa de anos, tipo teenagers, onde estava o Pirmin Trecu. A escola, que era ali na Boavista, só tinha dois rapazes e aí umas 30 raparigas. Então, ele perguntou se eu não queria ir, de borla. E aquilo era caríssimo. Foi perguntar ao cego se quer ver. Fui encantado.

\section{E o teu pai viu o espectáculo?}

Gostou muito. Primeiro ainda perguntou se eu não me importava que ele fosse, para não ficar enervado. DisseIhe para ir. Foi. Andava com as críticas na carteira para mostrar aos colegas, porque elas diziam bem de mim.

\section{Sentiste que podia ser o teu futuro?}

Não, era mesmo para me divertir, porque tinha um prazer enorme. Não, eu nunca fiz planos nenhuns para nada.

\section{Como foi esse primeiro envolvimento com a cena e os} bailarinos?

Fascinante. Eu estar ao lado dos grandes bailarinos dessa época [Armando Rosa, Patrick, Isabel Santa Rosa]. Fazíamos figuração com certo movimento, mas não dançávamos.

Um desses rapazes do ballet entrava em cena com balões e perguntou-me se eu queria trocar com ele, porque tinha medo que o reconhecessem. Fiquei encantado por ir à frente, dançando como uma gazela, com imensos balões e com duas bailarinas, uma de cada lado. 0 tal rapaz foi fazer uma personagem que levava barbas para não o reconhecerem. Vê lá como era o Porto nessa altura. Era horrivel! Eu não, eu estava-me nas tintas para que me conhecessem ou deixassem de conhecer. Só que eu nunca cheguei a ser nenhum bailarino de jeito, fazia as piruetas para a direita e nunca consegui fazer para a esquerda, desequilibravame. Entretanto também fui chamado para a tropa.

A tropa interrompeu a tua carreira de bailarino? Cheguei da tropa em1969. Tinham passado quatro anos. Já era muito velho. Iria ser bailarino de grupo. Não me apetecia. Eu pensava: "Se eu dançar, só se for no Parque Mayer". Mas isso não queria. Quando cheguei disse: "Não morri, mas tive de gramar dois anos na guerra, em África, agora vou divertir-me e fazer o que não fiz. Londres era o centro do mundo, eram os Beatles, os Rolling Stones, era aquele mundo incrivel. Era o meu sonho. Portugal era um atraso de vida, nós nem jeans tínhamos para comprar. Quando cheguei a Londres pela primeira vez, até me deu uma coisa de coração. Estive um ano a viajar.

De que modo as viagens pela Europa te transformaram? Viste espectáculos? Conheceste artistas?

Não, não conheci artistas. Vi espectáculos, vi. 0 primeiro que vi até me caíram os queixos. Foi Jesus Christ Superstar [de Andrew Lloyd Webber], a primeira versão. Cheguei a Londres no dia 22 de Janeiro de 1972, no dia dos meus anos. Andava ali pelas ruas, dum lado para o outro. De repente vejo o cartaz Jesus Christ Superstar. Fui à bilheteira, entregaram-me o bilhete e quando eu entro no teatro, levam-me, levam-me... estava na terceira fila! Abre-se o fosso com aqueles fumos, sobe uma cruz e eu vejo um homem no ar a cantar... comecei a chorar. Eu chorava, chorava que nem via nada, tinha de estar sempre a limpar. 
A última moeda

de Fernando Gomes,

Roller Bar, 1982

(Maruga, Fernando

Gomes) [Arquivo pessoal

de Fernando Gomes].
A última moeda

de Fernando Gomes,

Roller Bar, 1982

(Maruga,

Fernando Gomes)

[Arquivo pessoal d Fernando Gomes].
Vi também, nessa altura, no Teatro Drury Lane, E tudo o vento levou [com base no romance de Margaret Mitchell], em musical. Eu nem queria acreditar no que estava a ver: o incêndio, e o cavalo e a carroça a atravessarem o palco!

\section{Trabalhavas e viajavas?}

Não ganhava bem. Em bares. Não dava para grandes folias. E também foi uma fase do make love not war. Cheguei lá e ao fim de três dias já tinha arranjado companhia para o resto da vida, pensava eu na altura. Uma coisa loura, de cabelos compridos. [risos] Depois fui para a Alemanha. 0 "para o resto da vida" só durou seis meses!

\section{Foste levado pelo amor?}

Era o amor e conhecer outras pessoas. Nós pedíamos boleia travava-se logo ali conhecimento. Era andar por ali, de cabelos compridos e de viola ao peito. Dormia onde calhava! Conheci uma familia maravilhosa dum rapaz que nos deu boleia e me ofereceu Les fleures du mal [de Charles Baudelaire]. Eu falava (ou antes, arranhava) em todas as línguas - passava em Espanha, falava espanhol, passava em França, falava francês.

\section{E na Alemanha falavas o quê?}

A primeira coisa que eu aprendi a dizer foi "zwei Tassen Kaffee, bitte" que é pedir dois cafés. Odiei tanto os alemães que me recusei a falar alemão. Chegava aos sítios e, ao princípio, ainda falava em inglês, depois era em português. "Quero aquilo", apontava. Ao fim de três meses estava cansado. Pensei: "Eu tenho vinte e oito anos, tenho de fazer qualquer coisa. E o que é que eu quero fazer? É teatro. Ora eu, na Inglaterra, não me safo. Aqui, muito menos. Não, vou é para Portugal." E assim fiz. Vim para Portugal, num comboio de emigrantes que demorou três dias a chegar. Aquilo era um nojo. Muita comida. Ai, meu Deus, o cheiro! Sai da estação e fui para o Parque Eduardo VII, deitei-me a respirar. E cá fiquei.

Antes de passarmos à tua profissionalização, pensando no teu período da tropa, fala-nos das cartas que escrevias.

Ah, sim. Inventava. Não ia contar o que lá se passava.

Não tinha graça nenhuma. la lá afligir a minha mãe. Ela guardou essas cartas todas. Aliás, tenho-as eu agora. E depois punha por fora "Esta é muito bonita" ou "Esta fala disto". Eu recebia cerca de quarenta por semana, era quem recebia mais, porque também as escrevia. Trabalhava num escritório, no meio de mato. Não tinha nada que fazer e gostava de escrever. Romanceava. Por exemplo, em Bula a aldeia junto ao aquartelamento, havia um sítio onde
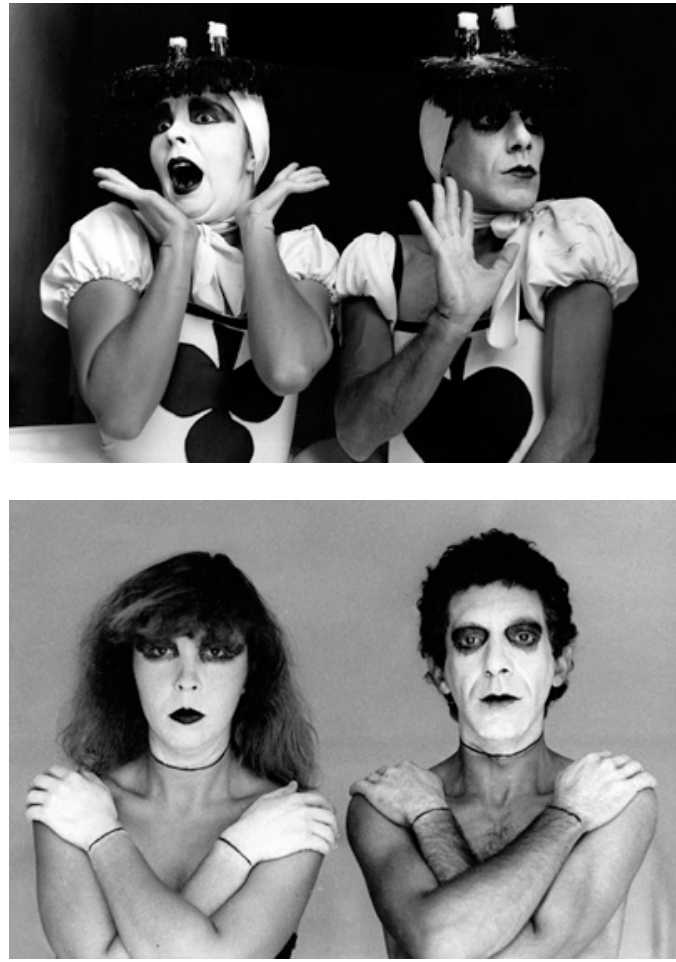

nós íamos beber cerveja, comer camarões, etc. Por essa rua passavam habitantes, elas muito bem vestidas, eles muito bonitos e elegantes. Portanto, a minha carta foi descrever aquela sequência de "passagem de modelos". Parecia um desfile de moda. Para a minha mãe sempre escrevi muito. Tenho o feitio dela. Tínhamos o mesmo sentido de humor. E não contava dos ataques, nem das guerras. Tinha sempre outras coisas para dizer.

Mas houve alguma situação de guerra mais delicada... Houve. Uma única. Eu tenho uma facilidade enorme em esquecer tudo o que de mau me aconteceu e recordar os momentos bons. Tive a sorte de não ir para o mato, nunca dei um tiro na Guiné. Eu estava no gabinete do $2^{\circ}$ comandante, que era um buraco na terra. Só trabalhava de tarde e à noite. E tinha autorização para me levantar tarde.

\section{A situação delicada...}

Ah! A situação. Eu cheguei à Guiné, formei logo um conjunto musical. Eu era o vocalista. Tentei tocar viola, dei logo cabo dos dedos. Acabou ali. Cantava. E sei até a primeira canção que cantei num baile em Bissau - "Hey Jude..." [dos Beatles]. Lá me divertia. Em Bule éramos atacados uma vez por mês e durante os 20 dias seguintes estávamos nas calmas. A gente já sabia. Chegavam sempre à hora do jantar. Um dia atacaram-nos de manhã, eu estava a dormir e quando acordei já o ataque tinha terminado! [risos] Vi lá muitos filmes no cinema ao ar livre. Os filmes todos do Roger Moore, do Santo. Era de 15 em 15 dias, acho. Também uma vez estava a assistir a um filme e houve ataque - "Eh pá que chatice!" - fomos para os abrigos. Acabou. Voltámos e acabámos de ver 0 filme. Uma pessoa habitua-se. É estranho. É dificil de explicar. E entretanto, houve um desastre: estávamos quase a vir embora, quase ao fim dos dois anos. Há sempre uma patrulha que sai para fazer um policiamento na 

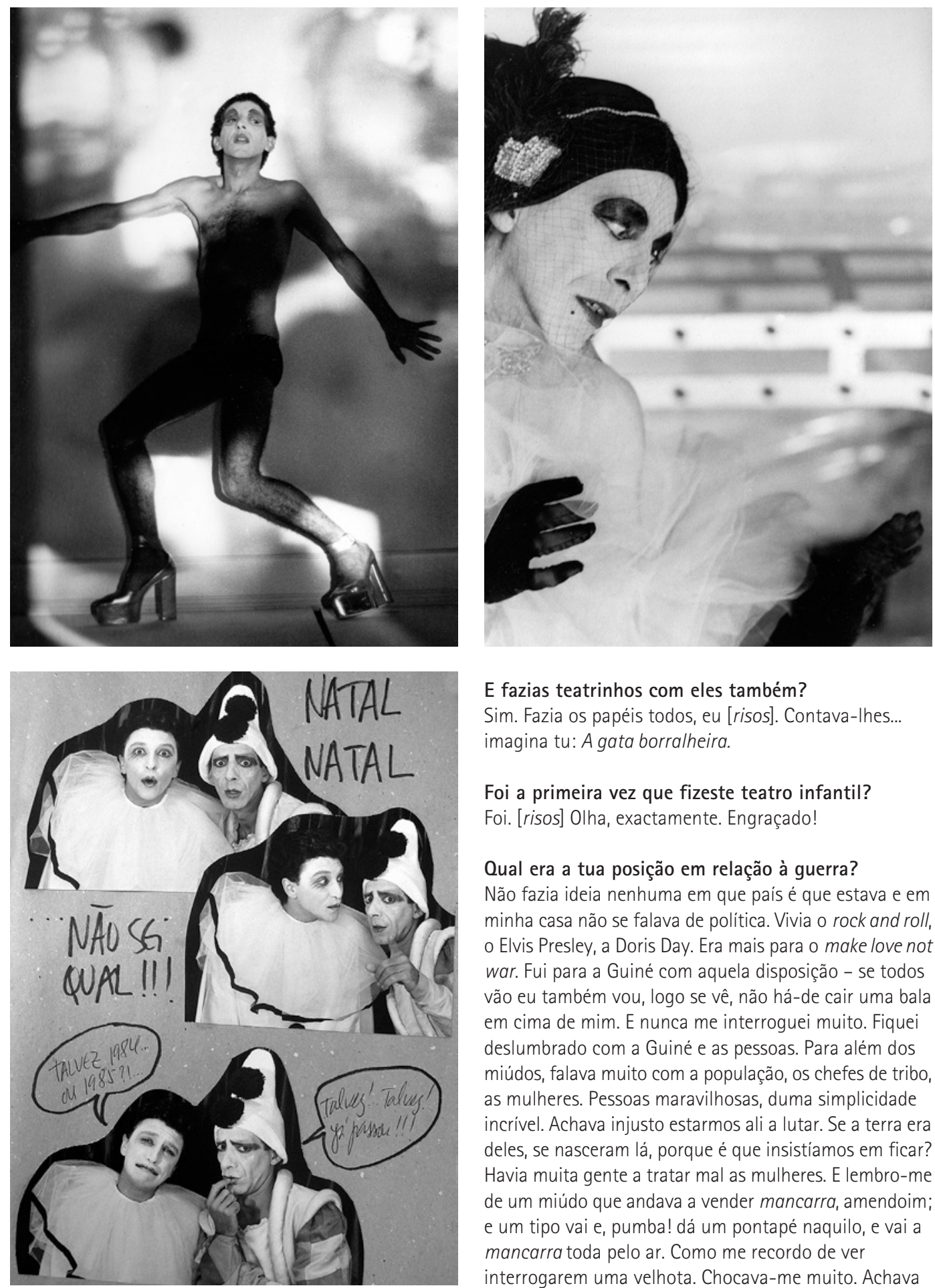

aldeia e depois regressa ao quartel, já noite. Quando regressaram da patrulha os soldados estavam a jogar às cartas, havia luz. Mesmo à porta da caserna, aquele que trazia o lança-granadas pousou a arma e encostou-se... e tinha a granada lá dentro, que ele devia ter tirado antes de entrar no quartel. Morreram imensos. Fiquei em estado de choque, estive calado durante uma hora. Uns gritavam, outros choravam, eram os helicópteros a chegar, a gente a ver mortos e feridos. Foi a única situação mais horrivel. E pronto, de manhã ia para a aldeia, os miúdos já me conheciam, contava-Ihes histórias, fazia teatro. Quando chegava vinham logo todos a correr ter comigo.
E fazias teatrinhos com eles também?

Sim. Fazia os papéis todos, eu [risos]. Contava-Ihes... imagina tu: A gata borralheira.

Foi a primeira vez que fizeste teatro infantil? Foi. [risos] Olha, exactamente. Engraçado!

\section{Qual era a tua posição em relação à guerra?}

Não fazia ideia nenhuma em que pais é que estava e em minha casa não se falava de política. Vivia o rock and roll, o Elvis Presley, a Doris Day. Era mais para o make love not war. Fui para a Guiné com aquela disposição - se todos vão eu também vou, logo se vê, não há-de cair uma bala em cima de mim. E nunca me interroguei muito. Fiquei deslumbrado com a Guiné e as pessoas. Para além dos miúdos, falava muito com a população, os chefes de tribo, as mulheres. Pessoas maravilhosas, duma simplicidade incrivel. Achava injusto estarmos ali a lutar. Se a terra era deles, se nasceram lá, porque é que insistíamos em ficar? Havia muita gente a tratar mal as mulheres. E lembro-me de um miúdo que andava a vender mancarra, amendoim; e um tipo vai e, pumba! dá um pontapé naquilo, e vai a mancarra toda pelo ar. Como me recordo de ver interrogarem uma velhota. Chocava-me muito. Achava que não tínhamos o direito de lá estar.

A revolução de 1974 coincidiu com a revolução da tua vida. Como foi viver as duas em simultâneo? $\mathrm{Na}$ altura do 25 de Abril foi tudo muito excitante. Andei ai pelas ruas aos gritos, aquelas coisas que todos fizemos. Era empregado de escritório e ganhava muito bem. Recordo-me de ter pensado na altura - "Olha, que bom isto acontecer! Os miúdos, que são agora pequenos, daqui a 20 anos já não vão ser tão atrasados como eu." Não aconteceu nada disso. Mas, na altura, foi um enorme entusiasmo. Logo a seguir fui para o Teatro Experimental de Cascais (TEC). Comecei a ensaiar O cerimonial para um
A paixão segundo Pasolini, de René Kalisky enc. Filipe La Féria, Grupo de Trabalhadores de Teatro da Casa da Comédia, Casa da Comédia, 1980 (Fernando Gomes) [Arquivo pessoal de Fernando Gomes].

Marlowe, Casa da Comédia, 1983 (Fernando Gomes) [Arquivo pessoal de Fernando Gomes].

Cadernos de Fernando Gomes (Fernando Luis e Fernando Gomes) [Arquivo pessoal de Fernando Gomes] 
Zigue-Zague

da Comédia, 1983

(Cândida Vieira,

Fernando Gomes, Maruga,

Rogério Samora,

Isabel Ribas,

Miguel Guilherme

[Arquivo pessoal de

Fernando Gomes].

Maria! Não me mates que

sou tua mãe

de Camilo Castelo Branco,

enc. Fernando Gomes,

Teatro da Comuna, 1988

(Isabel Ribas,

Miquel Martins)

[Arquivo pessoal de

Fernando Gomes].

Como é diferente o amor

em Portugal,

de Júlio Dantas,

enc. Fernando Gomes,

Teatro da Comuna, 198

(Elsa Galvão)

[Arquivo pessoal de

Fernando Gomes]. combate [1975] do Claude Prin, encenada pelo Avilez, sobre as mulheres da Comuna de Paris. Lembro-me da primeira leitura que fizemos, eu sempre à espera da minha frase, ai na décima folha. Está a chegar, está quase a chegar e a gente só tem aquela. É um suspense. [risos] Tínhamos de gritar para as mulheres: "Levantem-se putas! Levantem-se cadelas!". Fiquei logo rouco. [gargalhadas] Não sabia ainda colocar a voz. Os nervos.

Há a história de uma dor de dentes que te levou ao TEC.

Eu quando vim para Lisboa era tímido. Então tentei ir para o Conservatório, mas como tinha de trabalhar para me sustentar, era impossivel. Sempre sofri muito dos dentes, e pronto, lá está a tal história, fui ao dentista, arranquei um dente e vinha ainda muito inchado e mal disposto. Nesse dia não fui trabalhar e fui tomar um cafezinho ao Teatro Monumental, onde via muito a Laura Alves, o Paulo Renato. Ali era o mundo dos artistas, o Monumental ou o Monte Carlo. Entrou o Nuno Emanuel do teatro, com uma actriz, a Marilia Gama. Ele cumprimentou-me e ela olhou para mim e disse - "Olha não queres fazer teatro? Não queres ir para o Teatro Experimental de Cascais?" E eu disse: "Quero". "Então aparece hoje à noite para o ensaio". Fui logo. Nunca mais de lá saí. Ganhava no escritório nove contos e fui ganhar para o Avilez, mil escudos. Despedi-me da firma e ia aos ensaios da tarde e da noite. Aos da tarde só assistia, mas aprendi imenso a vê-los representar - a Isabel de Castro, o António Marques - e a observar o Carlos Avilez a dirigir. Estava com tanta atenção que ficava com dores de cabeça. Esse foi o meu grande curso. Já não tinha dinheiro para pagar o quarto e fui dormir para a carpintaria do TEC, com autorização do Avilez. Depois duns meses, fui para casa do António Marques, que me ajudou imenso, e ainda fui para casa de uma outra actriz, a Marília Costa. Estive três anos seguidos no TEC.

Quais as principais aprendizagens?

0 Avilez foi a base: "não respires aqui", "não representes de costas", "não cortes a personagem", "estás torto", etc.

Nunca mais regressaste ao escritório...

Recordo-me de ter sonhado, pouco tempo depois de ter ido ao dentista, e nesse sonho o dentista era o Fernando Midões. Saíam-me da boca clips de escritório! Tive ali um vómito de clips. [risos] 0 Midões foi das primeiras pessoas a falar de mim nas críticas, aquelas coisas que a gente, especialmente ao princípio, dá muito apreço. Ele gosta de conversar com os artistas. Em minha casa só disse que
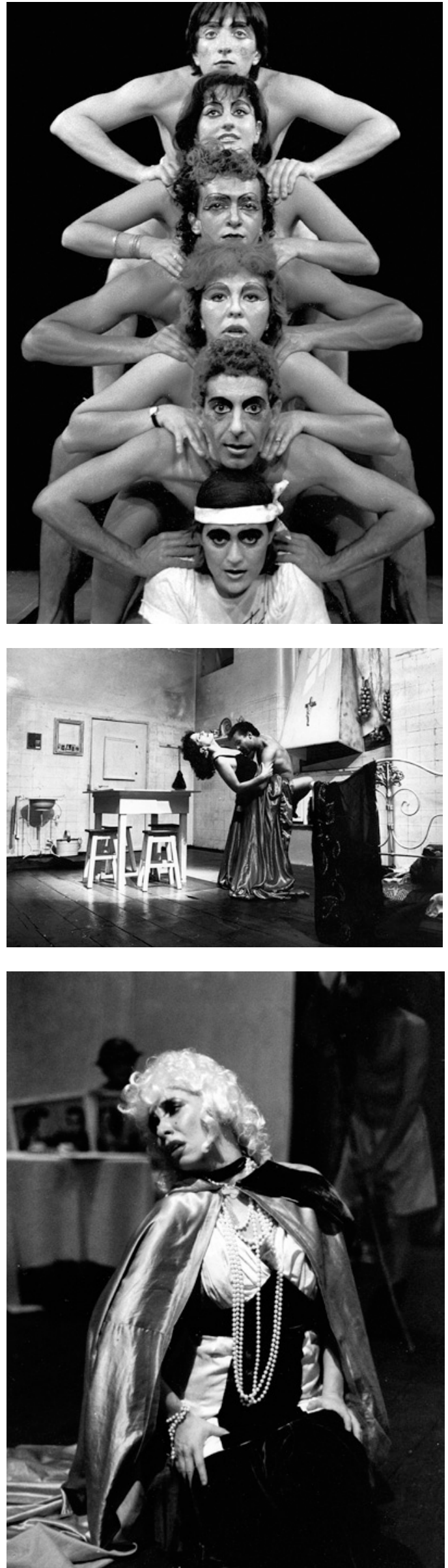


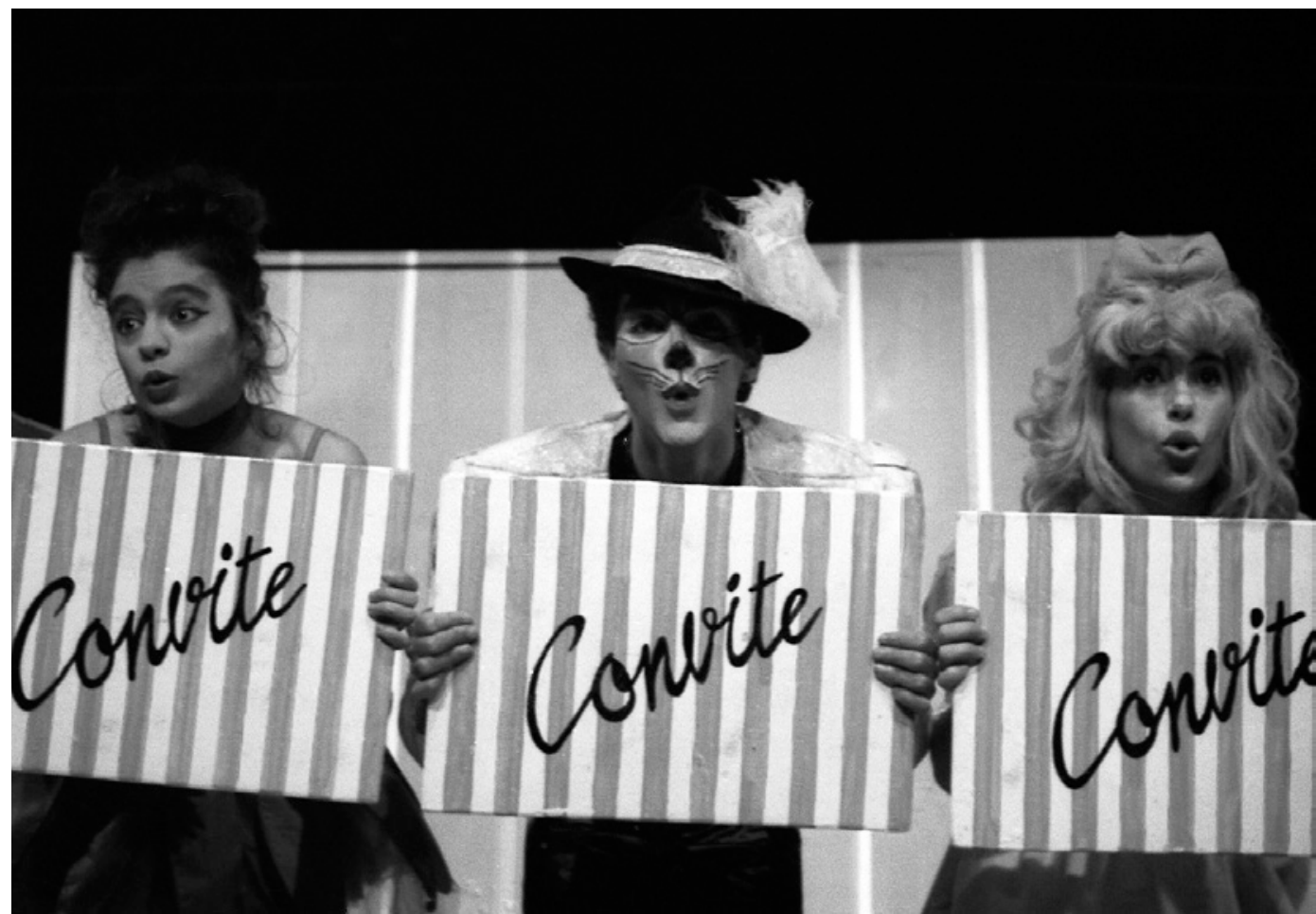

estava a fazer teatro passados 6 meses e dei a mim próprio um prazo de 3 anos para ver se tinha jeito. Achei que tinha.

\section{O TEC tinha muito público?}

Um público fixo. 0 Cerimonial para um combate esteve em cena no Teatro S. Luiz, na altura do 25 de Abril sempre cheio. Depois fizemos outro espectáculo político: Despedimento sem justa causa [de Júlio Maurício, em 1976], encenado pelo Rogério Paulo. Andámos pelo Alentejo todo.

\section{Onde é que apresentavam os espectáculos?}

Passámos por várias herdades que tinham sido ocupadas. Toda a gente ia. Nós chegámos a representar num palheiro, com música gravada, sem playbacks nenhuns. Durante o dia ajudávamos nos campos, a carregar os sacos. E depois, à noite, à luz de candeeiros de petróleo, representámos - Cerimonial para um combate, a seco, sem banda sonora. Foi fantástico. Fizemos o espectáculo em Casas do Povo. Em Baleizão, o palco da Sociedade de Recreio era tão pequenino que a gente não podia abanar as bandeiras, não tinha espaço. Mas resultava sempre.

\section{Que recordações guardas?}

0 povo em euforia. 0 António Marques fazia o operário torturado e na cena da tortura havia pessoas que desmaiavam. Era um delírio, as mulheres gritavam quando o torturavam. Havia no público quem tivesse familiares que tinham passado por aquilo. Eu fazia um dos fascistas e, fora de cena, eles até me diziam: "Ah! seu maroto!" [grita e ri]. Uma experiência única.

\section{E depois do TEC?}

Despedimo-nos alguns e reunimos um grupinho: Vladimir Franklin, Abílio Luis, do TEC, eu e o António Feio. Pegámos numa peça do Joaquim Cascais, $A$ inauguração da estátua equestre, sobre a estátua da Praça do Comércio. 0 Vladimir fez uma adaptação, eu escrevi umas canções, o António Feio tocou viola e construiu o cenário. Estreámos em Alcântara, em 1977, numa Sociedade de Recreio. Eu fazia muitas personagens: o Marquês de Pombal, um italiano, políticos, um soldado muito engraçado que o povo adorava. Um êxito. Mas não ganhámos dinheiro nenhum! Foi bom, mas durou pouco! Entretanto, o António Feio foi para a Rafael de Oliveira ${ }^{1}$ e quando precisaram de um outro actor, o António lembrou-se de mim. Fiz Os invasores [1977]. Mas ainda antes de a carreira terminar, pedi para me substituirem.

\section{Deixaste a companhia?}

Sim. Um dia cheguei a Lisboa e passei pela Casa da Comédia: "Ah! Filipe [La Féria], já não aguento aquela peça, ai que mal que eu faço!" Ele responde: "Vem para cá". E fui fazer A dama pé-de-cabra [com base na narrativa de Alexandre Herculano, em 1977], substituí-lo exactamente. Fiquei na Casa da Comédia muito tempo. Tudo aconteceu de forma muito natural.

\section{Onde conheceste o Filipe La Féria?}

Fez comigo a Ópera dos três vinténs [de Bertolt Brecht, em 1976/7] no TEC. Ele é da minha idade, mas começou a fazer teatro aos dezasseis anos. 0 Filipe era fantástico, contava histórias de teatro, de espectáculos que tinha visto (já nessa altura ele falava da Eva Péron [de Copi]) e eu ficava fascinado.

\section{E o trabalho-aprendizagem com o La Féria?}

0 Filipe sabe marcar, coreografar e encontrar o ritmo certo para determinada cena. Neste campo aprendi imenso com ele.

\section{E foste dirigido pelo La Féria.}

0 primeiro protagonista que fiz foi com o La Féria, em 
A ópera de três vinténs,

de Bertolt Brecht

e Kurt Weil,

enc. João Lourenço,

Novo Grupo / Teatro

Aberto, Teatro Aberto,

1992 (Fernando Gomes,

Sofia de Portugal)

[Arquivo pessoal de

Fernando Gomes].

Por alma de negreiros, filmado para RTP2, 1993

(Fernando Gomes,

Mário Viegas)

[Arquivo pessoal de

Fernando Gomes.

Cadernos de Fernando

(Fernando Gomes,

Elsa Galvão)

[Arquivo pessoal de

Fernando Gomes].
Fastudo! Faz-tudo!! Faz tudo!!! [1979]. Era maravilhoso o espectáculo, lindo! Foi o primeiro a esgotar lotações na Casa da Comédia. Era todo passado num circo, entrava a Adelaide João, a Teresa Roby, o João Medina, a Maria Dulce fazia a dona do circo. 0 teatro estava transformado numa pista de circo, com muitas luzinhas e uma orquestra ao vivo. Era a vida do Faz-tudo, que vivia para um sonho: o número dos cavalinhos brancos. Prometem-Ihe o número e nunca lhe dão... e ele sempre ali, a lutar e no fim mandam-Ihe os leões e matam-no. Foi nesse espectáculo que eu me tornei muito notado pelos colegas do teatro. Porque toda a gente foi ver. Tinha muito a ver comigo. Outra coisa que eu fiz muito bem foi a primeira novela: Todo o tempo do mundo. As pessoas diziam: "Ai, que trabalho fantástico!" Até tive um prémio. Não me custou fazer aquele homem que quer um mundo melhor. 0 Filipe foi a única pessoa que me disse: "Tu és um actor dramático." Dizem-me: "Tu devias era estar na Revista." Mentira, gosto de ver, mas não tenho jeito nenhum para aquilo. Não sou um cómico.

O homem dos sete instrumentos [1981] foi o primeiro espectáculo que fizeste especialmente dirigido à infância? Sim. 0 homem dos sete instrumentos era com a Paula Só e com o Paulo B. Sabes, um dos motivos que me levou a sair do TEC, independentemente de ter gostado de lá estar era só fazer um espectáculo por ano, meses a ensaiar, aquelas histórias dos subsidios e de não haver dinheiro. Comecei tão tarde, se só faço uma peça por ano, o ano tem doze meses, é muito pouco. Com o La Féria: de manhã montávamos o cenário de 0 homem dos sete instrumentos, à tarde fazíamos, e à noite era o Pasolini [1980] que esteve esgotado os seis meses que esteve em cena. Eu não parava. Entretanto, fui fazer, também lá na Casa da Comédia, um espectáculo de café-concerto, Zigue-Zague [1983] também escrito por mim. Não havia folga, metade da semana era o Zigue-Zague, a outra metade era o Marlowe, com a Sara Lima, o Luigi Abbondanza e o António Feio, portanto havia teatro todos os dias. Estiveram os dois espectáculos nove meses esgotados. Entretanto fui substituir o Luigi, no Marlowe. Já fazia dois espectáculos por semana, metade o Zigue-Zague, outra metade o Marlowe. Não contente com isso, porque tinha as tardes livres, pensei fazer um espectáculo a cantar. E à tarde ensaiava com o Sérgio António poemas do Botto. Fiz um espectáculo maravilhoso: Botto - teatro do ciúme e do amor [1984]. 0 La Féria viu umas cassetes de ensaio e disse: "Estreia-se já na Casa da Comédia". Esteve sempre cheio. Um êxito. Críticas belissimas. Por isso é que eu já vou em cento e trinta e tal espectáculos... não páro!
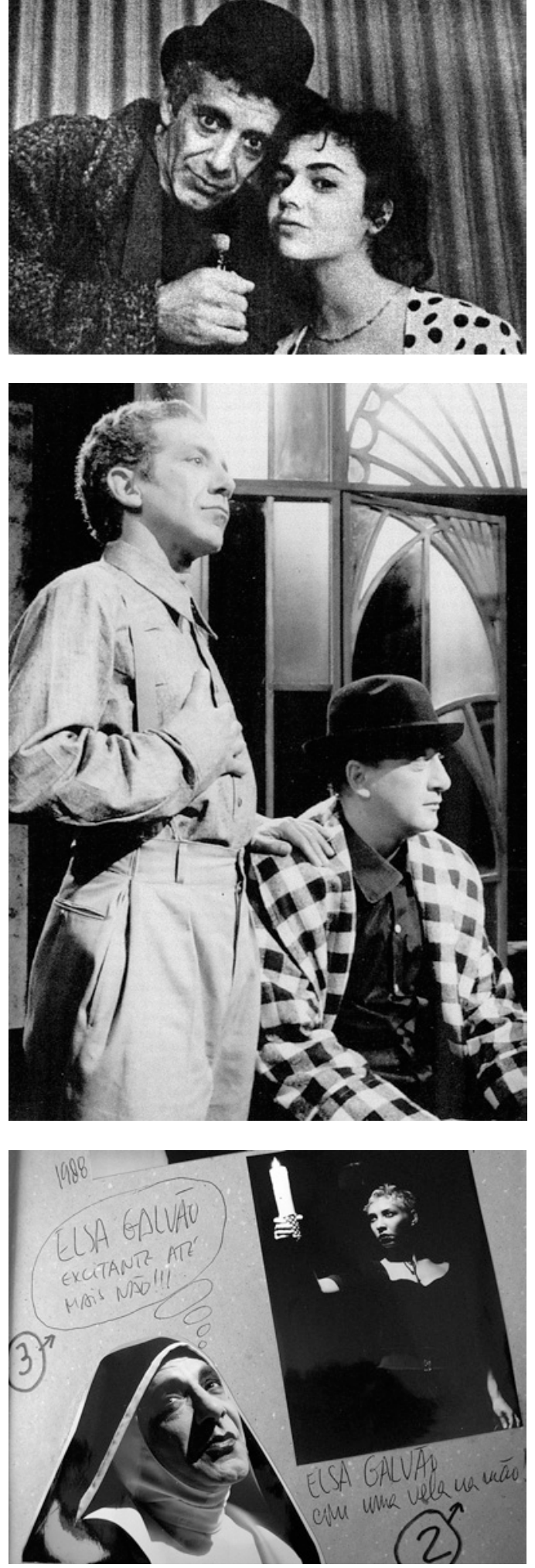

0 teu primeiro espectáculo de café-teatro que fizeste foi Cheira a esturro [1981].

Foi. Com o Paulo B. Comecei a fazer café-teatro porque ganhava muito mal. Então escrevi umas graças, a que eu hoje não acho graça nenhuma. Eram umas coisas tipo

"Hollywood-pobrezinho", "Carmens Miranda", depois umas conversas e uma canção. Fiz imenso tempo os ceguinhos que cantavam uns fadinhos. 0 êxito deve-se ao seguinte: gostávamos muito do que fazíamos. Divertíamo-nos 

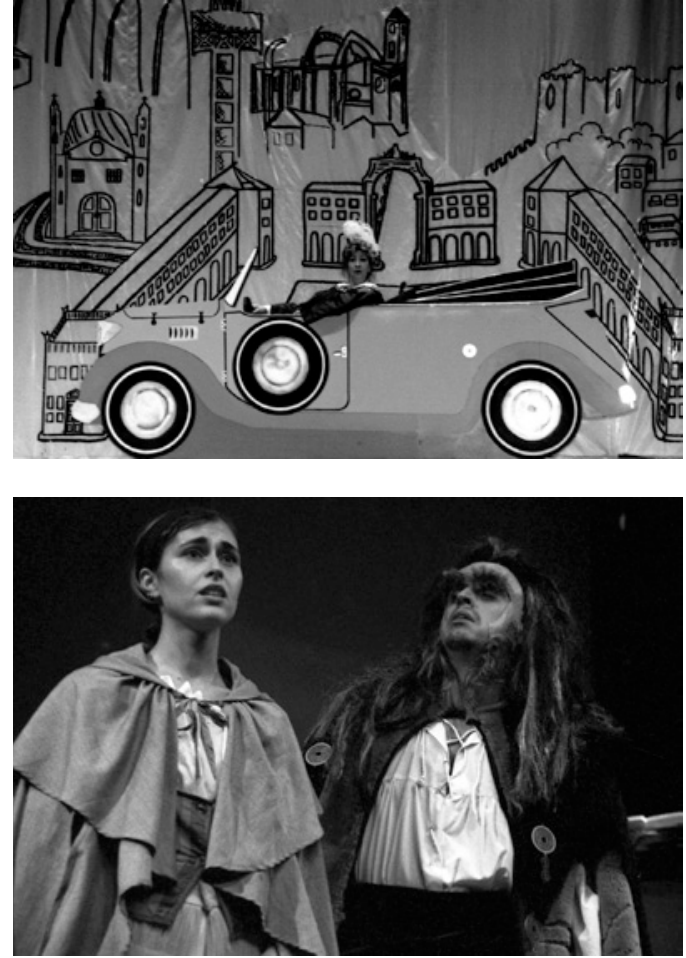

imenso e éramos muito simpáticos. Era eu, a Maruga e a Cândida Vieira. Sou tímido, mas no palco não. 0 Fernando Luis diz que aprendeu imenso a fazer café-teatro comigo, que foi a escola dele. Fizemos café-teatro durante meses, só os dois, no Porto, num bar do Centro Comercial Dallas. À uma da manhã, as pessoas saíam dos outros bares para ver o café-teatro e depois voltavam para os dancings. $\mathrm{E}$ os textos não eram nada de extraordinário, nunca fiz essas graças das mamas, do rabo, de revista, nada. Portanto era um espectáculo gracioso, simpático, cantava uns fadinhos e fazia versos cómicos.

\section{E como é que tu escolhias os actores?}

0 Paulo B. conheci na Casa da Comédia e também a Cândida Vieira, que era contra-regra, cantava muito bem e era engraçada. A Maruga era amiga dela. Trabalhava no Teatro do Nosso Tempo, do Jacinto Ramos. A Maruga falou-me da Isabel Ribas. Um dia, no Bairro Alto, chovia que Deus a dava, a Isabel Ribas a correr, cai-me aos pés a pedir para fazer café-teatro. Estava farta de fazer dramas. Entrou no Zigue-Zague onde fez uma inesquecivel cena de striptease.

Fazias tudo, escrevias, encenavas, fazias os fatos e eras figurinista.

Tudo. Pois, que remédio! Eu, a Maruga e a Cândida Vieira íamos comprar comida ao supermercado, comíamos nas esplanadas. Depois resolvemos estrear no Porto, aliás, estreei nos Modestos (que já não era Modestos). Como nenhum de nós tinha dinheiro e eu tinha casa no Porto, resolvemos ir para lá e vender o espectáculo. Fizemos um primeiro espectáculo na Comuna (o João Mota cedeunos a sala de Café-teatro) e com o dinheiro da receita comprámos bilhetes para a viagem. Imagina. Era a esse nivel. Depois, no Porto, o meu irmão conhecia o dono de um restaurante e nós pedimos-Ihe toalhas e pedimos mesas à Câmara do Porto. Fizemos o espectáculo nos

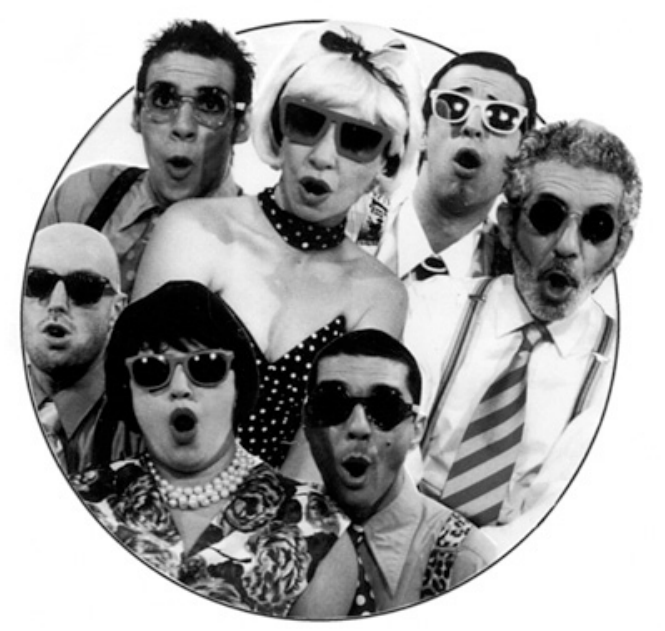

Modestos [Cheira a esturro] que estava vazio, nem se podia utilizar o palco. 0 cenário era um piano velho, enfeitado com pautas de música, cinzeiros, velas, as tais mesas e toalhas. E uns técnicos de lá ajudaram-nos a nivel de luz e som. Sem condições nenhumas. Um êxito!

\section{Eras o responsável pela produção?}

Nós é que fazíamos tudo. Às vezes tenho saudades da descontracção, do fazer e dividir igualmente por todos. A gente fartava-se de ganhar dinheiro, em comparação com o que se ganhava no Teatro Independente. Eu vivi anos só a fazer café-teatro. Não contente com isso, à noite ia para o Acapulco [1984/85], fazer um show à uma e meia da manhã. Eu, a Maruga e a Isabel Ribas. Sabes quanto é que eu ganhava no Acapulco? Quatro contos por noite. Não havia folga. Não parava.

Achas que o café-teatro, como diz o Fernando Luís, é uma escola?

É. Uma pessoa vai a um bar para conviver com alguém ou seja para o que for... de repente apareces e... tu tens de prender a atenção daquela gente, tens de ter ritmo, tens de saber responder se se metem contigo... tens de ser bom... percebes?

Só o actor, sem rede. Fazíamos o que agora chamam stand up comedy... mas não contávamos anedotas, tínhamos um texto base e construiamos personagens.

\section{Em Setúbal havia o Teatro de Animação de Setúbal} [TAS].

0 Carlos César convidou-me para fazer café-teatro, como os meus espectáculos tinham muito êxito. A ver se pegava em Setúbal. E pegou. Sempre esgotados. Foi uma época. Uma moda.

A passagem pelo Bando.

Muito curta.
Cinderela, revista portuguesa, de Fernando Gomes, Teatro Infantil de Lisboa, Teatro Maria Matos, 1994 (Fernanda Montemor) [Arquivo pessoal de Fernando Gomes].

A bela e o monstro, de Fernando Gomes, Teatro Infantil de Lisboa, Teatro Maria Matos, 2001 (Joana Manuel, Pedro Pernas) [Arquivo pessoal de Fernando Gomes].

Viva o casamento de Fernando Gomes, Teatro do Chapitô, 2001 (Carlos Macedo Paula Fonseca,

Elsa Galvão, Luis Pacheco, Rui Raposo, Pedro Pernas Fernando Gomes) [Arquivo pessoal de Fernando Gomes]. 
Osangue

a partir de Camilo Castelo Branco,

enc. Fernando Gomes,

Grupo Teatroesfera,

Espaço Teatroesfera, 2001

(Emanuel Erada,

Teresa Faria

António Filipe)

[Arquivo pessoal de

Fernando Gomes].

A vida trágica de Carloto

a filha da engomadeira,

de Camilo Castelo Branco,

enc. Fernando Gomes,

Klássikus, Teatro Há-de-ver,

2002 ([atrás]

Carlos Macedo, Isabel Ribas,

Luis Pacheco, Rui Raposo,

Fernando Gomes,

Paula Fonseca

[à frente]

Pedro Pernas e Elsa Galvão fot Pedro Lemon Garcia.

Divina loucura de Fernando Gomes,

Klássikus, Teatro Há-de-ver,

2003 (Pedro Pernas) [Arquivo pessoal de

Fernando Gomes].

\section{E a Comuna?}

Sim. Era outro estilo diferente do meu. Se quisesse ainda continuava a ganhar dinheiro a fazer os casais de fadistas do café-teatro... lá está, eu é que não sou pessoa para andar armado em cómico uma vida inteira. Tanto que deixei de fazer café-teatro. Tinha de evoluir para coisas diferentes: foi quando fiz a Maria não me mates, que sou tua mãe.

A primeira adaptação foi Alves $\mathcal{C} C^{a}$ [1986], a partir de Eça de Queirós, no TAS?

0 Carlos César convidou-me. Foi o terceiro espectáculo que lá fiz. Já era um espectáculo com uma sequência de números musicais através dos quais se contava a história do Alves \& $C^{a}$. Acabei por entrar nesse espectáculo para substituir o Fernando Luis. A história era a do Eça, com diálogos e personagens e depois havia momentos cantados. Entravam o Pompeu José que fazia o Alves, a Isabel Ganilho e a Manuela Couto, que ainda estava no Conservatório. Era uma miúda alegre, divertida, descarada e simples. Sentava-se ao meu colo, sempre contente. Foi amor à primeira vista.

Porquê esta opção de adaptar clássicos?

No caso do Eça de Queirós foi o Carlos César que pediu para fazer a adaptação. Depois continuei. Conhecia muitas peças de teatro português e nenhuma se adaptava ao que eu queria fazer. Autores mais actuais ou estrangeiros há sempre dificuldades, por causa dos direitos de autor. Então pensei: gosto tanto das obras do Camilo Castelo Branco, e do século XIX em particular, o melhor é fazer adaptações. Eu gosto de temas portugueses porque tenho consciência que é a minha realidade e sei fazer bem. Nas personagens do Camilo eu vejo a minha avó, o meu avô, as histórias que a minha avó contava e os dramas de todas as famílias.

0 "estilo Fernando Gomes" ficou conhecido pela adaptação / encenação dos textos portugueses: Camilo Castelo Branco, Almeida Garrett, entre outros. De que modo trabalhas a escrita?

Nem sei explicar como faço. São imagens que me passam pela cabeça. E eu não me drogo! Começo a ler o maior drama e imagino aquilo de uma forma tal que dá para rir. É trágico e cómico. Aliás, o trágico-trágico acaba por ser cómico muitas vezes.

Em relação ao humor, disseste numa entrevista ${ }^{2}$ que as pessoas representam mal na vida e isso é divertido. 0 teatro e o humor servem para "desmascarar" as pessoas? Claro. Estamos constantemente a depararmo-nos com
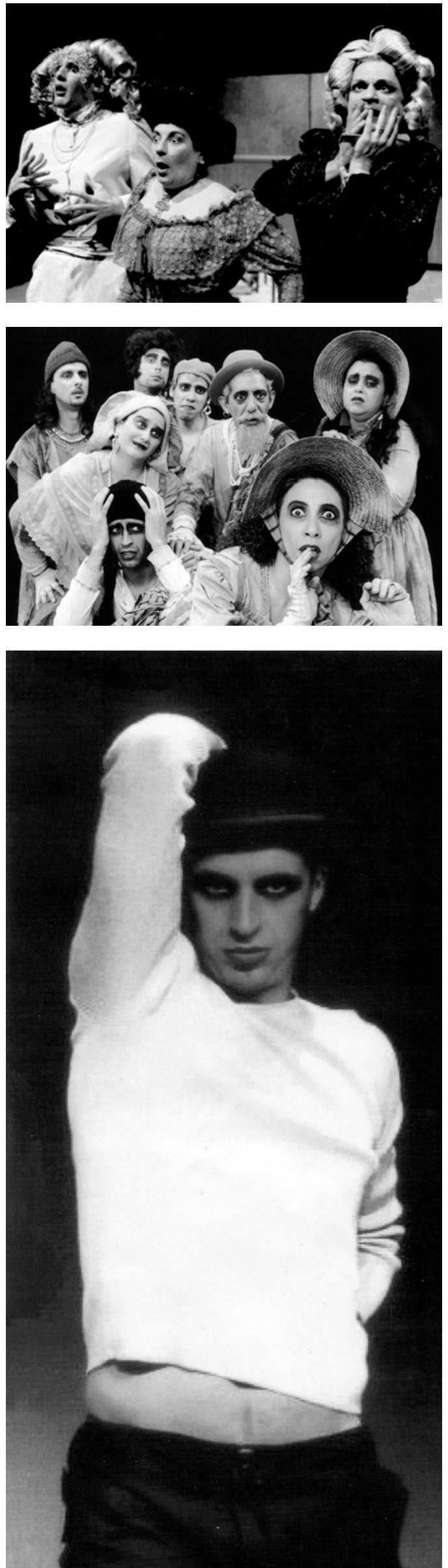

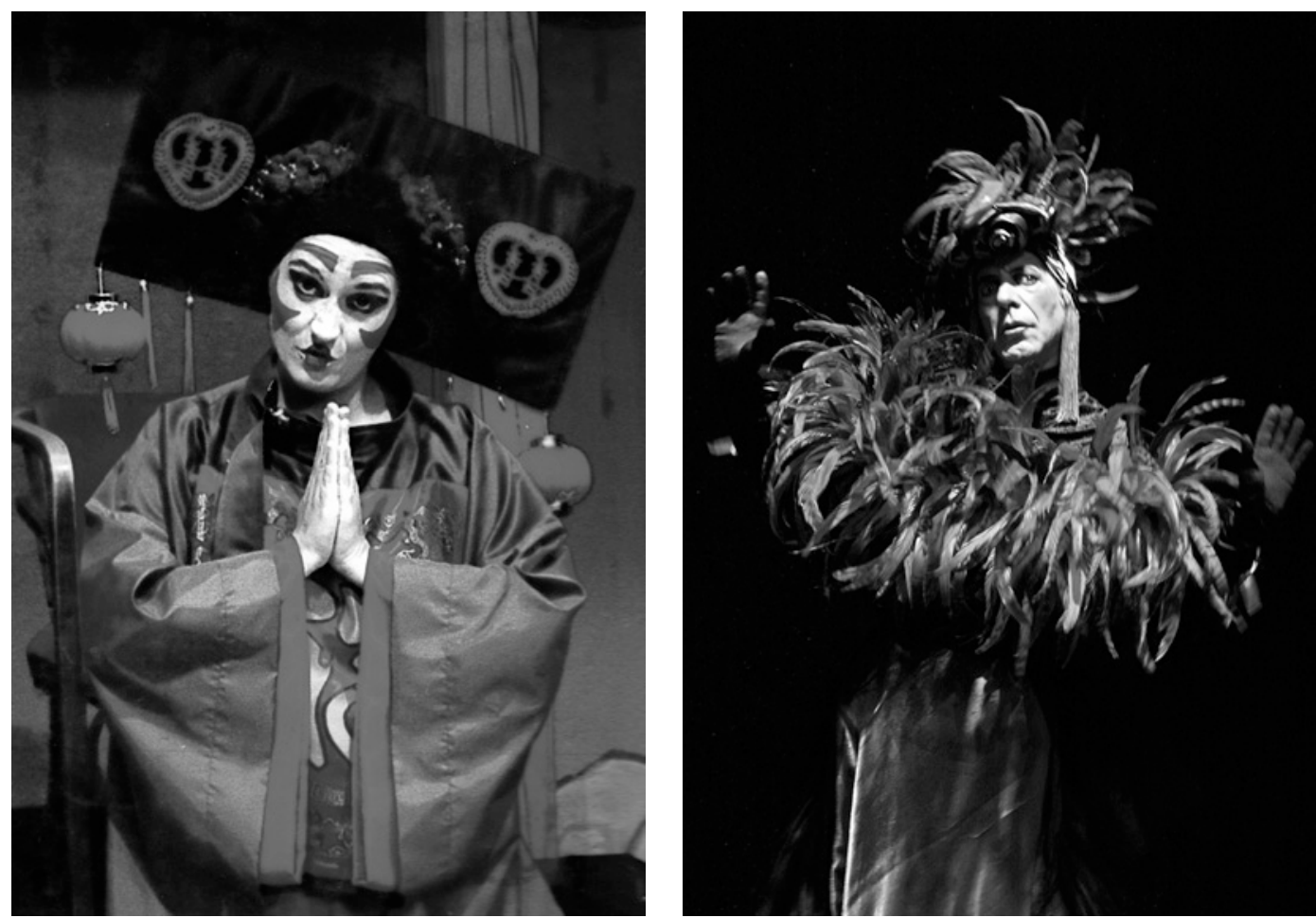

Nas asas do sonho, a partir da opereta de Offenbach, Ba-ta-clan, enc. Fernando Gomes, Klássikus, Teatro Há-de-ver, 2003 (Isabel Ribas) [Arquivo pessoal de Fernando Gomes].

Jekyll \& Hide,

baseado na obra de Robert L. Stevenson, enc. Fernando Gomes, Klássikus, Teatro da Comuna, 2005 (Fernando Gomes) [Arquivo pessoal de Fernando Gomes]. pessoas que têm uma vida muito fictícia. É uma "teatra" que as pessoas fazem. E podes caricaturar essas pessoas e torná-las ridículas, porque elas já o são.

As figuras religiosas, as freiras... o teu humor é também paródia e crítica de costumes.

[Para Teresa Faria] Tu já fizeste, n'0 sangue [2000], uma mulher igual a uma tia minha. Para as minhas tias tudo era sagrado. Eu escrevo sobre coisas que já vi, que conheço. Por exemplo, no Porto havia um grupo de três raparigas solteiras que viviam com uma tia, conhecidas como as Laranjeiras (tinham laranjeiras no quintal). As pessoas espiavam-nas pela janela, porque elas tinham amigos que iam lá à noite a casa, conviver com elas. Aquilo era uma "ordinarice" para a vizinhança. E não era nada. Ouvia-se música, riam-se muito e contavam histórias uns aos outros. No Alves \& C. ${ }^{a}$ havia umas personagens a que chamei as Manas Nespereiras, as amigas do Alves. Quando escrevi, inspirei-me nas manas Laranjeiras.

No teu processo de criação tens a obra de referência e o teu conhecimento sociológico do tipo de personagens. Fazes já a encenação?

Faço. Quando estou a escrever estou já a ver tudo. Há histórias que têm milhares de personagens. Eu tenho que contar aquela história com $\mathrm{x}$ personagens. Como escrevo para fazer, penso logo nos actores, quem tenho de desdobrar e pode entrar numa cena e noutra não pode. Faço logo a encenação.

\section{Começas por fazer um guião?}

Não. Vai-me surgindo. N'O sangue, por exemplo, algumas personagens existiam na história, outras inventei. Imagina as tias: sei o que têm de dizer, para dar continuidade à história. Mas cada uma delas tem uma característica, uma personalidade. Se me visses a escrever, como quando ia nos autocarros, a fazer caras e a representar cada papel...
Ponho-me na pele da personagem.

\section{E como é o fio condutor da história?}

Há uma coisa que utilizo muito, chamada a distanciação brechtiana [risos]. Que fui buscar instintivamente. Todo eu sou instintivo. E inteligente. Houve uma altura em que pensava que não era.

\section{É o narrador. Usas um processo brechtiano?}

Imagina que estamos agora a representar: eu posso descer ao proscénio e contar ao público o que vai acontecer a seguir e falar o que penso de vocês. Depois volto e dou continuidade à aç̧ão. Utilizo muito no TIL, porque são poucos actores e as histórias têm sempre grandes enredos. Escrevi agora a cena final. Ao reler chorei. Vivo as cenas. Era o regresso de um filho que tinha desaparecido e ele encontra-se com a mãe. E estas coisas do amor e da mãe e dos filhos tocam-me muito. Imaginei logo as luzes, a música a crescer, eles a abraçarem-se felizes... E chorei, chorei [risos]. E ri-me! Pareço parvo [risos]

Alguma vez te surpreendeste com um texto já escrito que reescreveste ao encenar?

0 que me surpreende muitas vezes, felizmente, são os actores. Também acontece com figurinistas. Que é ter uma ideia e eles conseguirem superar a minha ideia. 0 contrário também às vezes acontece.

Há uma linha de continuidade de trabalho? De escrita e de encenação? Assinalas alterações no teu percurso de escrita?

Não. Foi sempre o mesmo tipo de adaptação, mas nunca fico completamente satisfeito com o que faço. Acho que ninguém fica. Economicamente, estamos limitados a um tempo, demoro a ensaiar entre um mês e dez dias ou um mês e quinze dias. Depois de estrear percebo sempre que há coisas que podia ter feito melhor. Se pudesse apurar 
Du Bocage in love

baseado na vida e na obra de Bocage, enc. Fernando Gomes,

Klássikus,

Teatro da Malaposta, 2006 (José Nobre, Elsa Galvão, Carlos Macedo, Rui Raposo

Fernando Gomes,

Luis Pacheco)

[Arquivo pessoal de

Fernando Gomes].

Zé do Telhado, baseado no capitulo 26 das Memórias de Cárceres de Camilo Castelo Branco, enc. Fernando Gomes, Klássikus,

Teatro da Malaposta, 2006

(Paula Fonseca, Fernando Gomes,

Isabel Ribas)

[Arquivo pessoal de Fernando Gomes].

Cabare de Joe Masterof

Fred Ebb

enc. Diogo Infante

Teatro Maria Matos, 2008,

fotografia no camarim

(Fernando Gomes)

[Arquivo pessoal de Fernando Gomes]. mais. 0 que já notei foi que nos últimos textos escrevo muito melhor. Tento dizer tudo com o mínimo de palavras. Eu tinha um defeito que era estender-me. Espectáculos que foram um êxito e, agora, ao relê-los, não gosto. Cada vez tenho mais facilidade em desenvolver as histórias e a inventar enredos.

Em 1988, Maria não me mates que sou tua mãe foi um fenómeno teatral, numa época em que o público estava afastado do teatro. Como explicas esse sucesso? Foi aí que te encontraste como encenador?

Foi em Agosto. Ninguém estreava em Agosto e esgotou todos os dias. 0 sucesso vem do seguinte: qualquer espectáculo vive dos actores, são eles que estão ali no palco. 0 Maria não me mates que sou tua mãe tinha um elenco fabuloso: Fernando Luis, Adriano Luz, Rui Paulo, Isabel Ribas, Elsa Galvão, entre outros. Eram todos muito bons, novos e com uma vontade enorme de representar. Entregavam-se de uma maneira incrivel àquilo que estavam a fazer. Foi ensaiado na Comuna, num corredor. Eu ensaiava de manhã com eles, à tarde no teatro da Graça [Vieux Carré] e eles ficavam a passar texto e a rever. Para já a história é muito engraçada. É trágica. É a mulher que mata a mãe por causa do rapaz. Um dos êxitos desse espectáculo foi "boca a boca", depois, era gente de teatro, não era público de televisão. Esgotou... era uma sala de cem ou cento e tal lugares. E todas as semanas, havia notícias sobre mim no jornal Se7e. As críticas que começaram a sair eram muito boas. 0 espectáculo era muito bom, imaginativo e criativo. Era estranho, tinha mistura de ópera com fados. As freiras eram travestis. Uma que gostava muito de animaizinhos tinha pena das formiguinhas e das baratas. Falava com os animais. Havia o São Sebastião da Pedreira, o santo com as setas espetadas (o Fernando Luis), que estava com uma tanguinha de moedas. Uma tanga que a Elsa Galvão usava para fazer danças árabes nos bares. Um São Sebastião a quem a Elsa ia rezar, metia moedinhas numa caixa e o São Sebastião mexia-se e cantava. Era extraordinário.

\section{Teve apoio?}

Foi o meu primeiro subsídio. Deram-me mil contos. A Ribas era quem ganhava mais, tinha trabalhado imenso comigo sem ganhar dinheiro nenhum. Disse logo que a Ribas ia ganhar 40 contos porque se cheguei até ali foi por causa dela e doutras pessoas que me ajudaram. 0 Zigue-Zaque esteve nove meses em cena mais pela novidade. Alguns sketches eram maus. Nós é que éramos muito alegres e cativávamos o público.
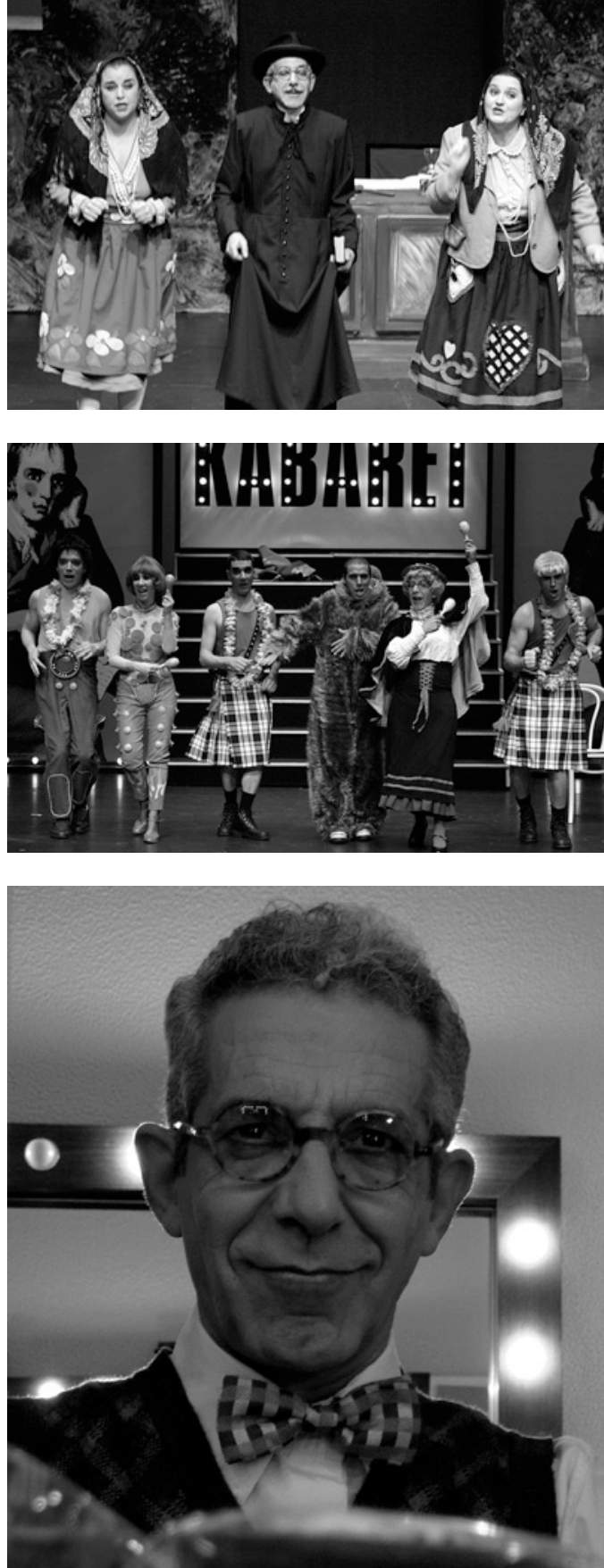

Ainda em 1988 fizeste, no Grupo de Teatro Hoje, Vieux Carré, de Tennessee Williams. Como foi trabalhar com o Carlos Fernando e um autor diferente dos que estavas habituado?

0 Carlos Fernando, que era extraordinário nesse tipo de encenações de Tennessee Williams, convidou-me para fazer o pintor Rouxinol, um dos papéis que mais gostei de interpretar. Assustei-me um bocadinho ao princípio. Mas o Carlos Fernando era fantástico e confiou muito em mim. Os actores eram todos fabulosos: a Isabel de Castro, a Maria José Pascoal, o Luís Lucas, o Fernando José Oliveira. 0 que foi diferente foi a quantidade de ensaios de mesa. Tantas semanas!... Eu sinto prazer em descobrir as personagens no palco. Contudo, o Carlos Fernando sempre disse que fiz bem e acho que fiz. Mas muito bem fiz duas ou três vezes. Não me deixo iludir por elogios, por prémios 


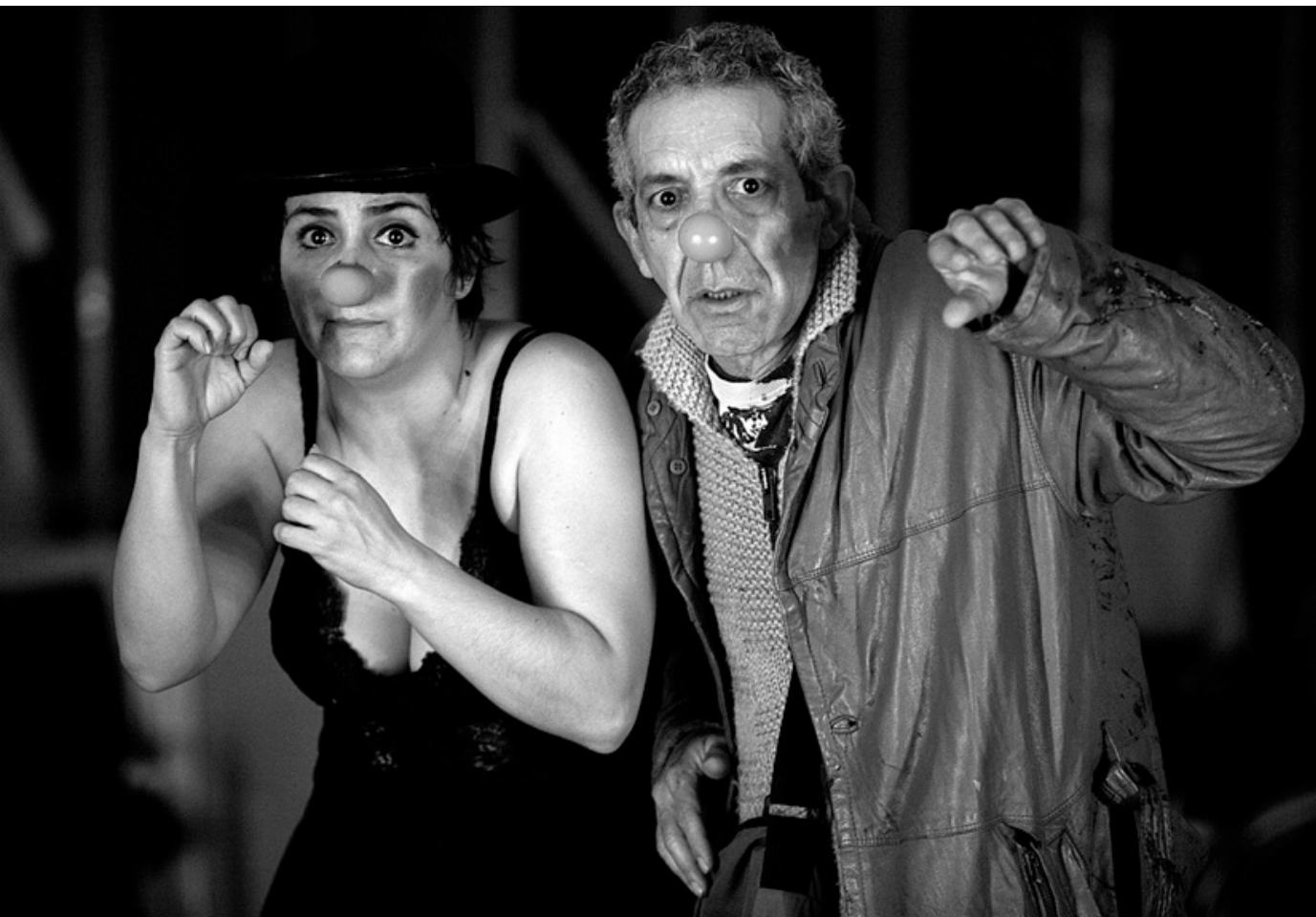

Comédia em três actos, de Carlos J. Pessoa, enc. Carlos J. Pessoa, Teatro da Garagem, Teatro Taborda, 2007 (Ana Palma, Fernando Gomes) [Arquivo pessoal de Fernando Gomes]. ou por críticas. Tenho noção quando faço bem e mal. E sei porquê.

\section{Gostaste de morrer no Vieux Carré?}

Adorei.

\section{E a morte na vida?}

Não me preocupa. Não. Gostava de morrer de repente. E não gostava de sofrer, não é que viva apavorado, mas .. a dor, a doença... Agora morrer, não. Já morri várias vezes, em palco. Até já me vi num caixão, com flores aos pés e tudo. Não me faz impressão. A dos outros é uma dor. De quem a gente ama é uma dor. Nem fales. A primeira foi a Maruga que eu andei louco, mas assim meses e meses. Perguntavam-me por ela e eu não dizia que tinha morrido, para não ter de dizer.

Nunca pensaste em encenar Tennessee Williams, por exemplo?

Como encenador, não. Gosto de ser dirigido, como actor. Eu como encenador gosto do musical, da comédia, do Camilo. Como actor gostava de fazer outra coisa... Fiz com o Luís Assis Uma casa na árvoree adorei ser dirigido.

\section{E trabalhaste com o João Lourenço, na Ópera dos três} vinténs [1992].

Um brilharete. Na altura eu estava a fazer a Rua Sésamo, e só podia ir aos ensaios da noite. 0 João Lourenço confiou cem por cento em mim. 0 meu texto era uma página e disse-me: "Faz à tua vontade". Porque aquilo tinha muito de café-teatro. E eu adorava estar encostado, na personagem de Mendigo, a vê-los representar. Depois lá dizia a minha graça e havia muito improviso porque eu conversava às vezes com as pessoas, oferecia-Ihes vinho... eu adorei fazer. A malta nova que lá estava dizia: "Ah, tu aceitaste este papel?" Era uma página. Eu pensei que era fantástico, porque fazia a ligação do espectáculo, o mais importante era a presença. E depois no fim perceberam, quer dizer, quase todas as noites eu levava "bravos" quando ia agradecer.

Nos últimos anos foste dirigido por Carlos J. Pessoa, em Comédia em três actos, em 2007, e por Diogo Infante, em Cabaret, em 2008. Como foi esta experiência de ser dirigido por encenadores de outra geração? Como já te disse, gosto muito de ser dirigido. Muitas vezes não me chamam porque sabem que tenho os meus espectáculos. Ultimamente têm chamado mais. É a idade. É uma alegria muito grande. Ser chamado é sinal de que gostam de mim. Um reconhecimento. Ainda agora o Monchique disse-me: "Quero que sejas tu." Estou a aprender com eles outras coisas. Não estou ali como encenador. Depois tento ver a forma como eles trabalham, que é a deles, e tento encaixar-me o melhor possivel.

Mas a grande permanência é no Teatro Infantil de Lisboa (TIL), desde 1990. Musical português. Uma referência desta década. Sentes-te realizado? Com a mesma companhia e a mesma estrutura?

Os melhores espectáculos musicais que fiz foram no TIL, onde tenho tido uma evolução enorme a nível de escrita porque são espectáculos mais complicados, tem o bailado, muitas personagens... um dia apareceram uns miúdos no Teatro Aberto, com o Carlos Macedo à frente a dizer: "Gostávamos muito que fosse lá para o TIL". Tinham uma salinha no Calvário. Muito pobre. Achei muita graça àquela simplicidade. E fiz o primeiro que se chamava Feliz aniversário [1990], onde tu entraste [aponta para Rita Martins]. Era uma história inventada por mim, muito simples. Umas variedades com um fio de história. Correu muito bem e seguimos com A grande aventura [1991] sobre o sonho do homem de voar. A plateia era como um avião, simples mas muito elaborado. Fizemos outro maravilhoso nessa sala pequenina que foi O soldadinho de chumbo [1992]. Naquele 


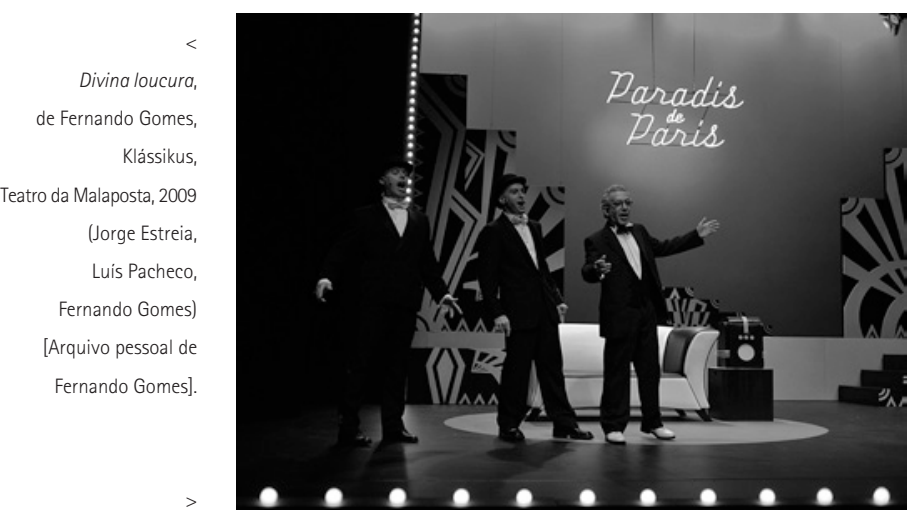

Mas afinal quem és tu, ó dona Maria da Fonte, de Fernando Gomes, Centro Dramático de Viana, Teatro Sá de

Miranda, 2008

(Tiago Fernandes,

Silvia Santos)

[Arquivo pessoal de Fernando Gomes.

A ilha encantada, de Fernando Gomes,

Klássikus,

Teatro da Malaposta

Tiveram feed back em relação à formação de públicos? Acho muito injusto tirarem o subsidio ao TIL. A justificação é que os espectáculos são bons, com muita qualidade, mas têm público. É estúpido porque para fazer aqueles espectáculos, com aquela envolvência, é preciso dinheiro. E é importante fazer aquele tipo de espectáculos: os miúdos saem de lá fascinados e ganha-se um novo público. Nota, eles estão esgotados sete ou oito meses seguidos. Têm uma média de sessenta mil espectadores por ano. Tenho falado com muitos pais que vão com filhos pequenos e os mais velhos já vão à Cornucópia. Se há algum trabalho
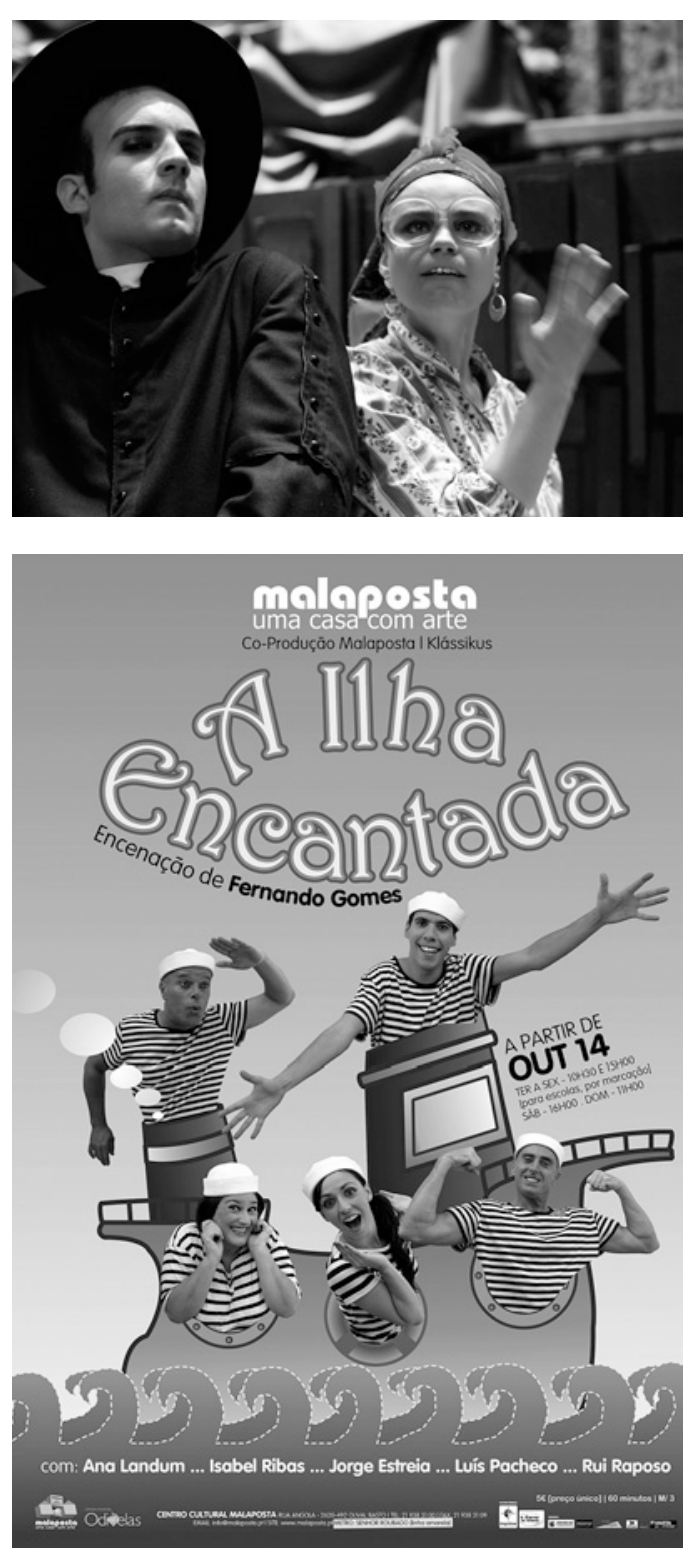

que eu tenha feito em prol do teatro em Portugal foi esse. Fui nomeado para um prémio de personalidade do ano por causa do trabalho que fiz no TIL. E bem merecido. Mas ganhou o Paulo Pires.

\section{Há uma preocupação pedagógica?}

Não tenho. 0 que é preciso é ter coração e saber falar com as crianças. É como a minha avó que me contava histórias. Nunca tive uma pedagoga ao meu lado a corrigir a minha avó. 


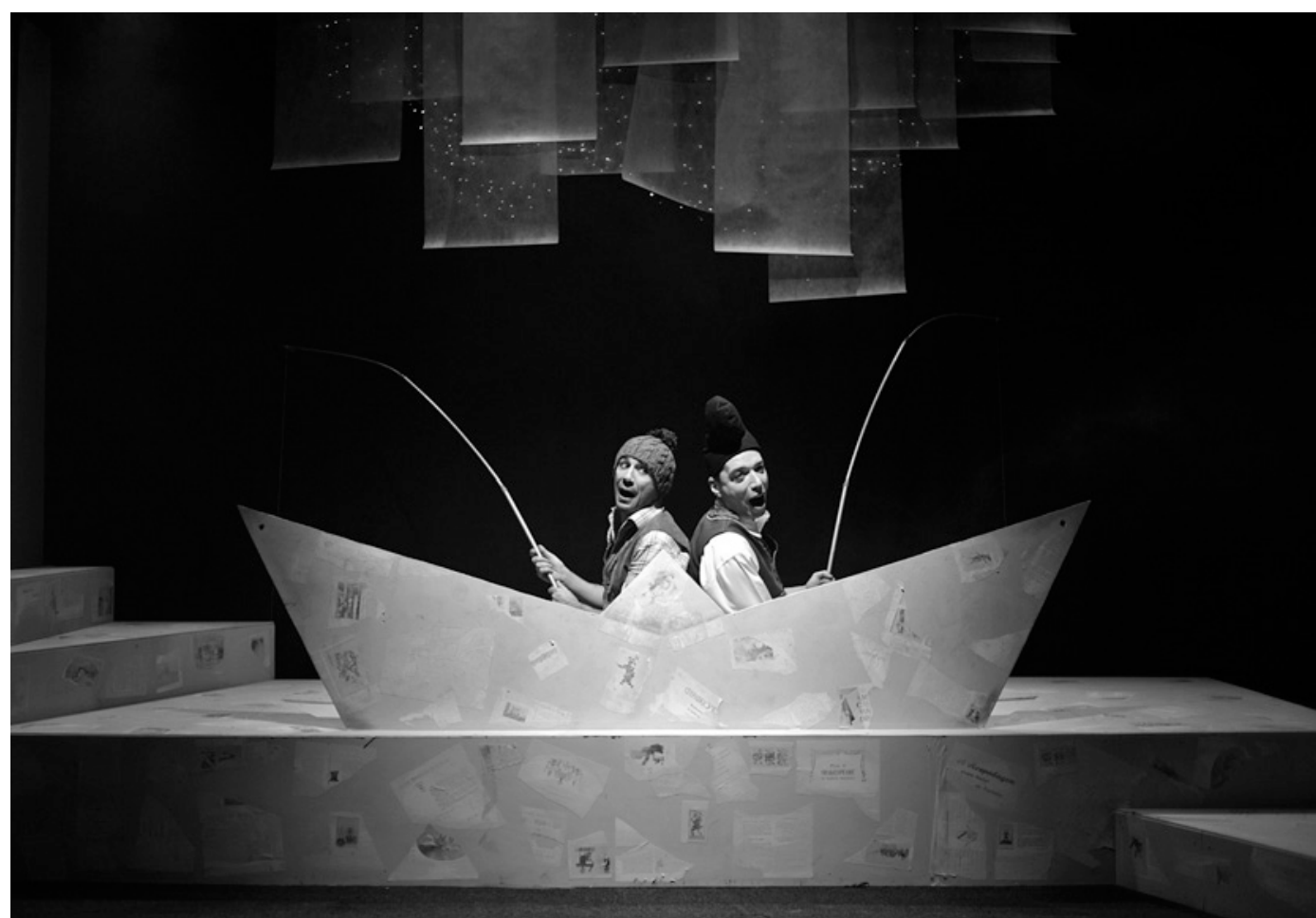

\section{E gostas de crianças?}

Gosto. E fascina-me o público da terceira idade. Velhotes. É o público de que eu mais gosto. Não faço espectáculo nenhum que não ofereça bilhetes a velhotes ou a lares, àqueles que não podem. Adoro a alegria com que eles estão ali na plateia.

$\mathrm{Na}$ tua carreira tens ido ao Porto, pontualmente, trabalhar com a Seiva Trupe, em Porto Alegre [2005] e $O$ casamento [2002]. Regresso às origens?

De forma alguma. Não tenho nada o espírito "o Portinho é a minha terra". Aquilo era um atraso de vida, senti-o na pele. Se saía com uma roupa moderna era logo insultado na rua, porque os homens andavam de cinzento. Camisa de flores, como a gente via nas revistas? Insultos. Calças à boca-de-sino? Mais insultos. Provincianos até dizer chega!!!

É por isso que, nas tuas peças, aparecem aquelas personagens à margem da sociedade?

Tenho fascinio por marginais. Das experiências mais fantásticas que tive, em Lisboa, foi apresentar espectáculos em bares de alterne com a Maruga e a Isabel Ribas. No Acapulco éramos tão bem tratados e respeitados! A Maruga e a Isabel punham-se em biquíni no palco, com plumas à cabeça e tínhamos uns sketches cómicos, cantores e o corpo de baile. Senti que havia mais respeito pelos artistas tanto pela parte dos donos e do pessoal, como pela parte do público.

Mais recentemente, em Viana do Castelo, escreveste e encenaste Mas afinal quem és tu, ó Dona Maria da Fonte [2008]. Foi resultado de uma investigação sociológica e histórica?

Fui estudar a época, a revolta, a D. Maria, até o Garrett entrava. É uma paleta de cores contando a vida da Maria da Fonte e a importância que ela teve. Mas nada é certo, há muitas lendas. 0 que é óptimo porque dá para fantasiar e reinventar à volta desse tema. Adorei o espectáculo e correu muito bem. No ano seguinte, fiz Rosa enjeitada [2009] onde já entrava como actor. Foi um êxito de rebentar costuras. Até o "galinheiro" tinha gente. 0 teatro é lindo.

Ao tempo da tua passagem pelo Teatro Municipal Maria Matos, começaste a encenar ópera. Ba-ta-clan [1999]. Mais tarde, As madamas do Bolhão [2002] e A vingança da cigana [2007]. É neste percurso que surgiu $O$ chapéu de palha de Itália de Nino Rota, no Teatro Nacional de S. Carlos [TNSC], em 2011?

Esses espectáculos são praticamente todos com música do Offenbach, óperas pequenas, ligeiras. 0 produtor era o Eduardo Viana, que eu já conhecia dos tempos do TEC e que tem uma enorme admiração por mim. Conheci, no Ba-ta-clan, o João Paulo Santos, que agora está no S. Carlos e que fez a direcção musical do Nino Rota. Foi ele que se lembrou de mim para encenar o espectáculo, porque gostou muito de trabalhar comigo. Eu fiquei muito surpreendido, não estava nada à espera de ser chamado para o Teatro Nacional de S. Carlos. Foi uma experiencia fantástica. Adorei o convívio com os cantores de ópera. Gostei imenso da experiência, da música ao vivo e de ter tantas pessoas em palco. Correu tudo muito bem.

\section{Foi fácil dirigir os cantores?}

Facílimo. Os cantores estavam loucos para começar. Dois ou três já tinham trabalhado comigo, como o Carlos Guilherme e o Luís Rodrigues. Às vezes eu acho que é mais fácil trabalhar com cantores do que com alguns actores de teatro. 0 entusiasmo, o esforço, a disponibilidade, a atenção às minhas indicações. Porque nem todos representam maravilhosamente. Mas todos com uma entrega... Fiquei amicissimo deles. Até um grupo de sete cantores, que quer fazer um espectáculo itinerante com árias de ópera, pediu-me para escrever um texto e encenar. 
Foi-te útil a relação com a ópera e a opereta na infância e juventude?

0 que foi muito útil foi o que o meu pai me deu a conhecer. Os Gilbert \&t Sullivan conheço desde os cinco anos. E este saber da ópera, da música e do canto vem de pequenino. Isso é que teve uma grande influência no meu futuro. Fo o que os meus pais me transmitiram.

E a relação com as óperas e bailados em que entraste La serva padrona, etc.?

Ficou o fascínio. Ver ali os artistas. Para mim o mundo sem artistas não tinha graça nenhuma. São eles o sal do mundo. Se não houver música, bailado, teatro, pintura, o que é que fica?

Como foi ser professor de Teatro, na Escola Superior de Teatro e Cinema de Lisboa, a encenar Mestre UBU [2004]?

Não estava nada à espera. Como não tirei nenhum curso para ser professor. 0 Carlos Pessoa, que conhecia mal, telefonou-me para eu dirigir o trabalho final do curso dos alunos de teatro. Eles têm de fazer um trabalho em função de uma peça onde vão representar, fazer os figurinos, tudo feito pelos alunos e orientado pelos professores. Chamaramme a mim, porque achavam que fazia falta o meu estilo na formação dos alunos. Todos conheciam o Maria não me mates que sou tua mãe. 0 trabalho com os alunos foi uma experiência engraçadíssima. A peça escolhida por eles foi o Ubu. Eu tinha doze ou catorze alunos e o Ubu tem quatro, cinco actores. Como todos iam ser avaliados, fiz uma adaptação de modo a todos terem o seu tempo. Caíram-me nos braços. Tive uma trabalheira, mas se me meto nas coisas é para ir até ao fim. 0 espectáculo correu muito bem, foi o que teve mais gente. Ficaram todos contentes. Mas o talento ou tens ou não tens. Não se aprende.

3 A vida trágica de Carlota a filha da engomadeira (2002), Romeiro, Romeiro, quem és tu? (2004), Jekyll
Finalmente a Klássikus, que tem apresentado o seu trabalho no Teatro Municipal Maria Matos, na Comuna, no Há-de-Ver, no Chapitô, no Teatro da Luz e, mais recentemente, no Teatro da Malaposta ${ }^{3}$.

Eu nunca tive aquele sonho de ter um teatro ou uma companhia. Ou se tive foi há muito tempo. Depois desisti. A Klássikus apareceu em 2002. Os subsídios, os poucos que tinha recebido, vinham no meu nome e depois os impostos iam para mim. Portanto, foi mais uma questão burocrática para formar uma associação cultural.

\section{Como surgem as co-produções com o Teatro da} Malaposta?

Em 2006, não me deram subsídio. Não tinha dinheiro nenhum. Quando não tenho nada para fazer invento. $\mathrm{E}$ pensei: "Vou fazer um espectáculo sobre o Bocage!" Já tinha feito um no TAS, mas agora diferente: com sketches, mais popular, divertido. Falei com a Elsa [Galvão], com um actor de Setúbal, o José Nobre, que tinha feito o Bocage, com o Luís Pacheco, o Rui [Raposo] e propus-Ihes ensaiar sem ganhar e tentar vender o espectáculo. Falei com o Manuel Coelho, que está a fazer um trabalho fantástico na Malaposta, e combinámos que ensaiávamos e estreávamos lá. Como teve muita gente ele pediu para continuarmos em Outubro, mas já pagando ordenados. Conclusão: a Malaposta é que produz, é que paga ordenados.

Qual a tua relação com a política de apoio à actividade profissional? Achas que deve existir?

Deve existir. Mas o dinheiro está mal repartido, como tudo neste pais. Falei-te no caso do TIL, que para mim é dos mais flagrantes. Os que decidem, dizem: "Tem lotações esgotadas, não precisam." Nem vão ver os espectáculos. Cortaram tudo. Estão-se a marimbar para as crianças que não votam e são o futuro do país. Estão-se a marimbar para os velhos porque não fazem falta nenhuma. E estãose a marimbar para o teatro e para a cultura. Eu, tendo possibilidades de ajudar, fico muito contente. Não tenho nada de meu. Só pedia subsídios porque sempre me preocupei com as pessoas com quem estava a trabalhar. Houve espectáculos que fiz com dinheiro que ganhei nas novelas da televisão. Quando fiz a Vida trágica de Carlota a filha da engomadeira, fiz tudo com o meu dinheiro. Gastei e paguei os ordenados. Não estava à espera de receber nada em troca, nem considero perdido. Portanto, a minha relação com o dinheiro é essa.

Talvez sejas a única pessoa em Portugal que faz uma média de 4 produções por ano, centro e trinta e dois espectáculos entre 1974 e 2010 . Como consegues? 


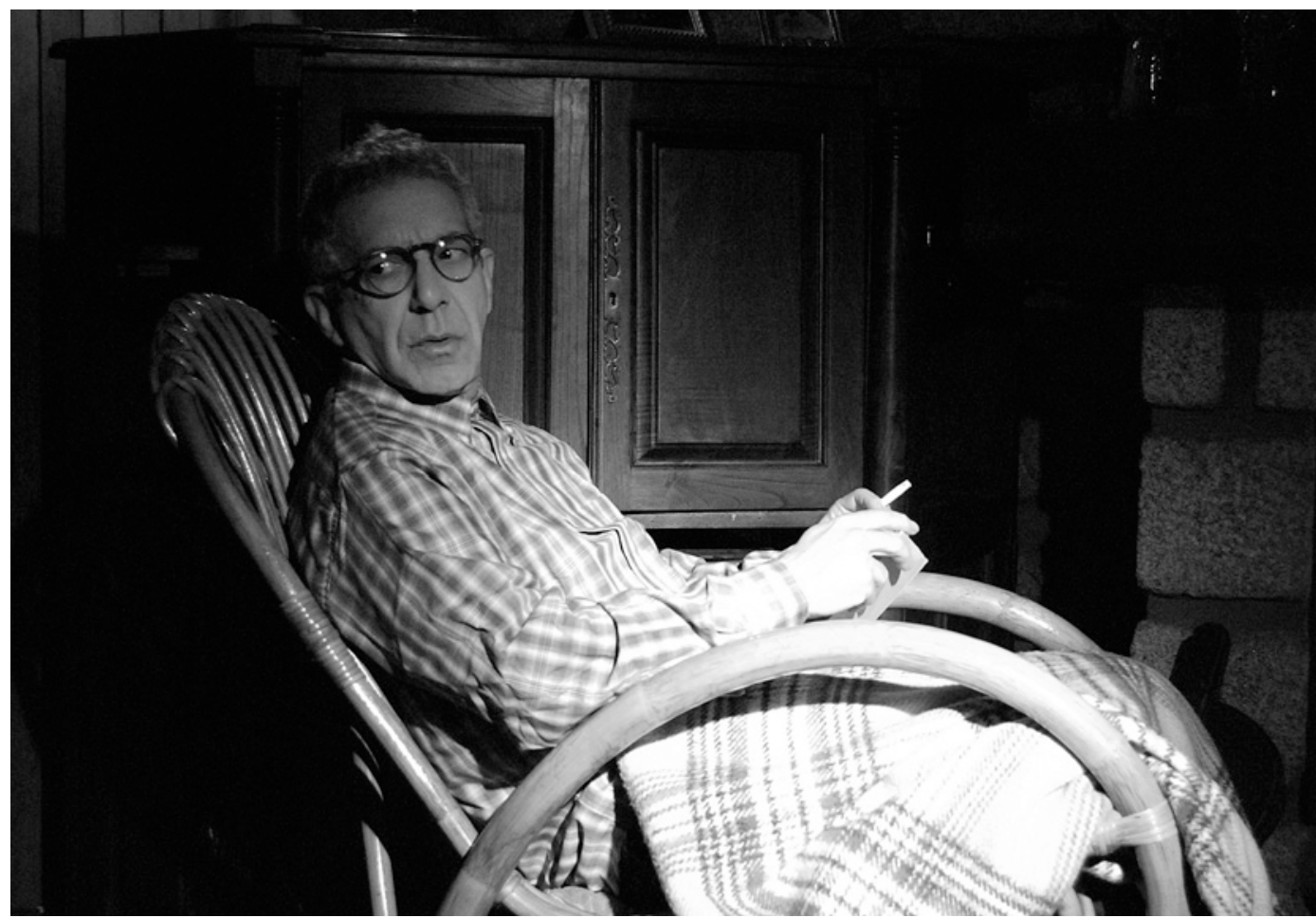

Sou muito organizado. Faço muitas listas. Adoro. Faço mapas para não ter de pensar muito: acordo, levanto-me e olho para o mapa... Poupo tempo. 0 meu período de ensaios é mais produtivo do que aquilo que tenho visto por sítios onde passo. Conversam tanto no meio dos ensaios. Eu não. Divirto-me muito mas é a ensaiar. Sempre fui assim organizado.

\section{Escreves sob pressão?}

Não. Eu divido. Por exemplo, calculo um mês para escrever uma adaptação. Sem pressas. Mas antes de escrever já estive cinco meses a pensar na peça. Quando começo a escrever já sei as caras das personagens e as caracteristicas. Demoro mais ou menos um mês. 0 mais difícil é encontrar o fio condutor da história e das personagens. A partir do momento em que encarrilei depois é rápido. A seguir revejo, corrijo e, quando ensaio, volto a corrigir. Não quer dizer que esteja irrepreensivel, mas está feito.

És assim organizado desde pequenino? Os teus pais já eram organizados?

0 meu pai escrevia tudo numa agenda. Uma vez, em miúdo pedi um par de sapatos. Nós não éramos ricos. Ele chamoume e disse: "Olha, está aqui, este mês comprei para o teu irmão, de maneira que agora não posso comprar para ti." E eu percebi. Eu nunca senti que era pobre, mas não tínhamos muito dinheiro. Quando ainda era muito pequenino fazíamos aquele cerimonial de escrever as cartas ao Pai Natal. E o meu sonho era ter um comboio de corda. Mas era um brinquedo caro para o meu pai. Tinha outras coisas, mas o Pai Natal nunca podia encontrar o comboio de corda [corre para o quarto e traz um comboio de corda]. Quando fiz cinquenta anos, o meu irmão mais novo ofereceu-me o comboio de corda que eu tanto queria! E no Natal ponho-o aqui a andar à roda. Somos muito queridos na minha família.
Ao longo da vida trabalhaste em espaços / teatros radicalmente diferentes: desde o TNSC até ao bar Acapulco. Onde é que te sentes mais confortável? 0 espaço condiciona-te?

Depende do tipo de espectáculo. Eu sinto-me confortável em função das pessoas com quem estou a trabalhar e não do espaço. 0 que me fascina é chegar a um sítio e adaptar, olha, O quiosque, com os Persona, no Clube Estefânia.

Adoro chegar a sítios esquisitíssimos, encenar, aproveitando os próprios espaços. Adorei o Chapitô. Então estar numa tenda de circo, respira-se logo outra coisa.

Em televisão e cinema tens tido alguns sucessos como nas séries Rua Sésamo (o professor), A minha família é uma animação (avô do Neco), ou Os malucos do riso e ainda em telenovelas, como Todo o tempo do mundo (o cantador). Escolhes os trabalhos para televisão? Não. Não cheguei a esse estatuto. Como actor não gosto de fazer televisão. Ponto final. E não sinto nem metade do à vontade que sinto num palco. As câmaras não me fascinam. Mais uma vez, são os afectos. 0 Júlio Isidro viu o Zigue-Zague e contratou-me. Aqueles sketches, que tinham imenso êxito no teatro, ali não eram nada. Há muita coisa que, para ser filmada, tem de ser adaptada. E eu próprio percebi que não funcionava e saí do programa. Depois surgiu-me a Rua Sésamo e eu aceitei muito contente. Começou aí a minha independência económica. Ai foi uma aprendizagem. Trabalhávamos todos os dias e a linguagem era muito simples, para miúdos, não tinha de fazer grandes representações. Viamos, repetíamos, uma produção como deve ser. 0 ambiente era muito simpático, estava o Vitor Norte, a Alexandra Lencastre, todos mais novos do que eu. Depois disso, as duas coisas que fiz bem foi o atrasado mental em Todo o tempo do mundo e a série A minha família é uma animação, com o Fernando Luis e com a Ana Bustorff. Isso era um ambiente fantástico e tínhamos o feed-back 


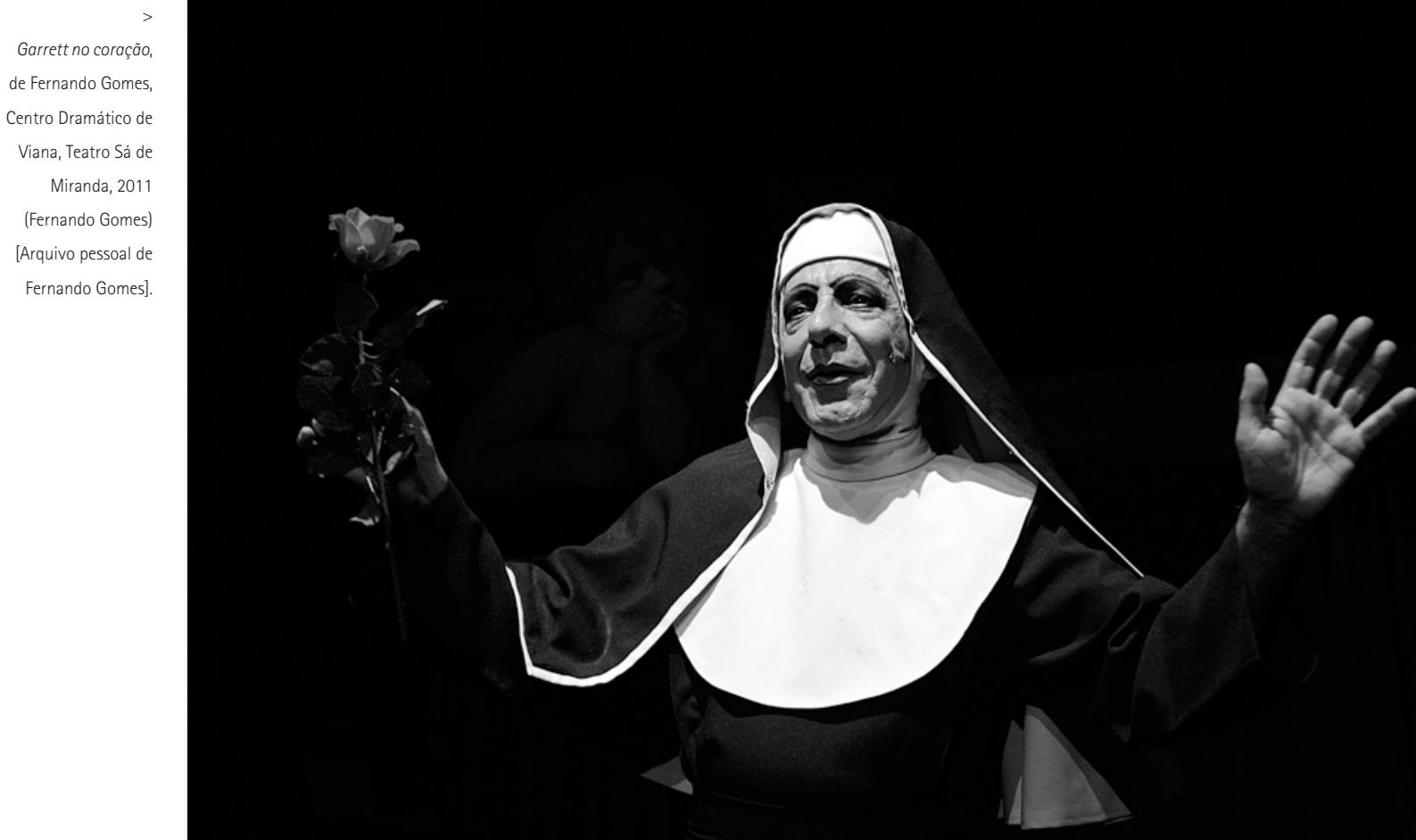

das câmaras. Trabalhei muito para a SPFilmes, eles tratavam os actores maravilhosamente bem. Sentia-me num larzinho.

Mas se os programas tiverem qualidade pode levar as pessoas ao teatro?

Com certeza! Olhem, fiz um filme para a televisão de que gostei muito. Foi o Por alma de negreiros. Fazia o Almada Negreiros desde novo até morrer e o Mário Viegas fazia o Fernando Pessoa. Fisionomicamente, fiquei quase igual ao Almada Negreiros. Era um texto maravilhoso, do Almada Negreiros.

Alguma vez puseste a hipótese de deixar a profissão? Nunca.

Se tivesses todas as condições que sonhas, que espectáculo ou projecto gostavas de fazer e com quem? De certeza com as pessoas com quem comecei a trabalhar e acompanho sempre, como a Isabel Ribas e a Elsa Galvão. Mas como tenho gostado de conhecer outras pessoas noutros sítios, também adoraria trabalhar... Tu serias uma delas [para Teresa Faria] porque eu adoro o teu tipo de representação.

0 teu projecto de sonho seria um grande espectáculo onde todos teriam papel, num grande teatro, dentro da linha do musical...

Com texto de Camilo Castelo Branco, que tem quinhentas personagens. Imagina: tinha vinte actores, velhos e novos, e escolhia um texto de Camilo, onde só tenho de cortar personagens, porque ele tem quinhentas mil. Dentro da onda do Maria não me mates ou d' 0 sangue, que é um estilo que gosto muito, mas mais em grande, com um palco maior, um bruto cenário, com cenas em simultâneo.

Dizes "o meu dinheiro vai todo para a rainha", é em Londres que te encontras?
Nunca fui de férias para outro lado. Uma semana chega. Lá não penso em nada. E Londres tem muitas coisas diferentes e criativas. Eu não consigo estar parado. 0 facto de fazer muito teatro, de manhã e à tarde, não me cansa, porque eu gosto. Era incapaz de estar uma semana na praia, numa esplanada, a olhar para o mar. Preciso é de um sítio para escrever. Dantes era nos cafés mas agora é em casa, no computador.

Os teus pais viram-te representar? 0 que disseram? A minha mãe sim. 0 meu pai morreu bastante novo. Só me viu na ópera La serva padrona. A minha mãe, moderna e inteligente como era, vinha até Lisboa sozinha e viu os espectáculos todos. Muitas vezes, aqui, punha música e ficava a bater o pé. Até aos oitenta e tal. Morreu com noventa e tal.

Se escolhesses só uma referência da tua vida quem era? A minha mãe. Ela está em todo o lado. É como se estivesse cá.

Tiveste uma infância feliz. E és uma pessoa feliz? Dentro do que se pode ser feliz. Estás a ver o meu lado simpático, agradável e normal. Mas quando caio em mim... preocupo-me com o que se passa no mundo e isso não me deixa feliz. Quando penso na juventude, aqui e em todo o mundo... é horrivel, esta violência, a desigualdade... por isso eu não ligo aos políticos... se fosse jovem era capaz de revoltar-me. Optei por viver sozinho, devido às minhas características. Gostei de pessoas, tive várias relações. Tive de tomar uma decisão - estar sozinho e de vez em quando sentir ausência. Preciso de muita respiração. Agora, sinto-me contente com a vida que levo. Sinto-me um privilegiado no meio deste mundo. Vejo as pessoas todas com graves problemas. Faço o que gosto, estou com as pessoas de quem gosto, tenho o amor de outras pessoas. Sei que não estou sozinho. 